\title{
Matematik Derslerinde Web Tabanlı Uzaktan Eğitime İlişkin Matematik Öğretmenlerinin Görüşleri
}

\section{Perspectives of Mathematics Teachers Regarding Web-Based Distance Education in Mathematics Courses}

\author{
Büşra Kilit ${ }^{a^{*}}$, P1nar Güner ${ }^{b}$ \\ a İstanbul Üniversitesi-Cerrahpaşa Lisansüstü Eğitim Enstitüsü, Matematik Eğitimi Bölümü, 34320, İstanbul/Türkiye. \\ ORCID: 0000-0002-1126-877X \\ b Dr. Öğr. Üyesi, İstanbul Üniversitesi-Cerrahpaşa, Eğitim Fakültesi, Fen ve Matematik Bölümü, 34320, İstanbul/Türkiye. \\ ORCID: 0000-0003-1165-0925
}

\section{MAKALE BİLGISI}

\section{Makale Geçmişi:}

Başvuru tarihi: 30 Eylül 2020

Düzeltme tarihi: 10 Aralık 2020

Kabul tarihi: 16 Aralık 2020

\section{Anahtar Kelimeler:}

Matematik Eğitimi

Matematik Öğretmenleri

Web Tabanlı Uzaktan Eğitim

\section{ÖZ}

$\mathrm{Bu}$ çalışmanın amacı matematik derslerinin web tabanlı uzaktan eğitim ile yürütülmesine ilişkin matematik öğretmenlerinin görüşlerini incelemektir. Fenomenolojik araştırma deseni ile yürütülen çalışmada katılımcı grubunu 19 ortaokul matematik öğretmeni oluşturmaktadır. Araştırmada veri toplamak amacıyla araştırmacılar tarafından hazırlanan yarı yapılandırılmış görüşme formu kullanılmıştır. Elde edilen veriler içerik analizi yöntemi ile analiz edilmiştir. Matematik öğretmenleri web tabanlı eğitimin avantajlarını tekrarlanabilirlik, bireysel farklılıklara uygunluk, öğrenme etkinliklerinin çokluğu, kendi hızında ilerleme ve maliyetin azlığı kavramları ile dile getirmiştirler. Dezavantajlarının öğrencilerle iletişim kuramamak ve öğrencileri kontrol edememek olduğunu düşünmektedirler. Matematik öğretmenlerin çoğunluğu web tabanlı uzaktan eğitimin faydalı olduğunu fakat matematik eğitimi üzerinde etkili ve verimli olmadığını düşünmektedirler. Öğretmenler firsat eşitliği konusundaki sıkıntıların giderilmesini web tabanlı uzaktan eğitimin kalitesini artırmak için önemli görmektedirler.

\section{A B S T R AC T}

This study aims to examine the perspectives of mathematics teachers about the teaching of mathematics courses via web-based distance education. In the study carried out with the phenomenological research, the participants group consists of 19 middle school mathematics teachers. In the research, semi-structured interview form prepared by the researchers was used to collect data. The data obtained were analyzed by content analysis method. Mathematics teachers expressed the advantages of web-based education as repeatability, compliance with individual differences, multiplicity of learning activities, progress at own pace and low cost. The disadvantages were not being able to communicate with and control students. The majority of mathematics teachers thought that web-based distance education was useful, however, they believed that it was not effective and efficient for mathematics education. Teachers have found it important to improve the quality of web-based distance education by eliminating the problems regarding equal opportunities.

\section{Giriş}

Çağdaş eğitimin özelliklerinden birisi talep edenlerin sayısal çokluğu ve coğrafi dağınıklığıdır. Geleneksel ve örgün eğitim mekân ve araç-gereç yoksunluğu sebebiyle bu talebi karşılamada yetersiz kalmaktadır (Özdil, 1986). Kaya (2006) eğitimin yeterince yaygınlaştırılamamış olması, fırsat ve olanak eşitsizliğinin sürmüş olması ve eğitimde standartların sağlanamamış olmasından dolayı örgün eğitimin en iyi olma özelliğini yitirdiğini belirtmiştir. Bunun üzerine ele alınan sorunların çözümü olabilecek "uzaktan eğitim" kavramı ortaya çıkmıştır. Uzaktan eğitim geleneksel eğitimden farklı olarak yer, yöntem, amaçlar, zaman, öğretim yaşı ve benzeri sınırlara bağlı kalmayan, özel olarak hazırlanmış yazılı

\footnotetext{
* Sorumlu yazar/Corresponding author

e-posta: busra.kilit@ogr.iu.edu.tr
} 
gereçler, kitle iletişim programları ve kısa süreli yüz yüze öğretimin bir sistem bütünlüğü içerisinde kullanılarak yürütülen eğitime denmektedir (Girginer, 2001). Kaya (2006) ise uzaktan eğitim kavramını "Geleneksel öğrenmeöğretme yöntemlerinin sınırlılıkları nedeniyle sınıf içi etkinliklerini yürütme olanağının bulunmadığı durumlarda, eğitim etkinliklerini planlayıcılar ile öğrenciler arası, iletişim ve etkileşimin özel olarak hazırlanmış öğretim üniteleri ve çeşitli ortamlar yoluyla belirli bir merkezden öğretme yöntemi” olarak tanımlamıştır.

Uzaktan eğitimi organize yapıda ilk sunan üniversitelerden biri 1886 'da ilk uzaktan öğrenme ağını kuran Pennsylvania Devlet Üniversitesi'dir. Farklı yerlerdeki öğrencilerine verdiği eğitimi dönemin iletişim aracı mektupla gerçekleştirmiştir (Bulurman, 2002). Ülkemizdeki uzaktan eğitim çalışmaları 1920'li yıllara dayanmaktadır. Bu yıllarda yalnızca fikir düzeyinde kalan uzaktan eğitimin ilk somut adımı 1950 yılında Ankara Üniversitesi Banka ve Ticaret Enstitüsü'nün girişimi ile atılmıştır. Bankacılık sektöründe çalışanlara mektupla eğitim verilmiştir. Sonraki yıllarda, çeşitli kurum ve kuruluşlar tarafından mektupla eğitim çalışmaları sürdürülmüştür. Özellikle Anadolu Üniversitesi tarafından sürdürülen posta ile eğitim programları başarı yakalamıştır (Toptaş, 2001'den aktaran Odabaş, 2003).

Web tabanlı eğitim, uzaktan eğitimi destekleyen, web aracılığıyla hazırlanmış, zamandan ve mekândan bağımsız olarak erişim olanakları sunan ve ulaşabilmek için bir ağa bağlanmayı gerektiren eğitim şeklidir (Kaya, 2006). Web tabanlı eğitim literatürde "Sanal eğitim", "İnternet tabanlı uzaktan eğitim", "İnternete dayalı eğitim", “İnteraktif uzaktan eğitim", "Asenkron elektronik eğitim", "E-learning” gibi değişik kavramlarla ifade edilmektedir. Bu çalışmada "Web tabanlı uzaktan eğitim" kavramı kullanılacaktır. Web tabanlı uzaktan eğitim için farklı mekanlarda bulunan eğitimci ve öğrencinin bilgisayar ağı bulunan bir platforma ve plana ihtiyacı bulunmaktadır (Bulurman, 2002). Web tabanlı uzaktan eğitim uygulamaları senkron, asenkron ve karma olacak şekilde yapılmaktadır. Öğrenci ve öğretmenin eş zamanlı olarak yaptığı ders senkron; öğrencinin öğretmenden, zamandan ve mekândan bağımsız olarak ders materyali ile öğrenme faaliyeti gerçekleştirmesi asenkron; ikisinin birlikte kullanıldığı sistemler karma olarak tanımlanmıştır (Şen, Atasoy ve Aydın, 2014).

Odabaş (2003)'a göre web tabanlı uzaktan eğitimin toplum için sosyolojik, psikolojik, mali ve kültürel açılardan birçok avantaj1 vardır. Hem ulusal hem uluslararası standartlar gözetilerek oluşturan eğitim ortamının mekân sorunu olmadan oluşturabilmesi, ekonomik olması, teknoloji aracılığıyla içeriklerin zenginleştirilmesi bu avantajlardandır. Web tabanlı uzaktan eğitim sisteminde öğretim bireyin öğrenme hızında ve yönetiminde gerçekleşmektedir (Yalçınkaya, 2006). Bayram (2002) oturum yönetimi, veri tabanı ve web tabanlı programlama dilleri gibi kişiselleştirebilir hizmetler sunulması ve zengin öğrenme ortamlarına olanak tanınması konusunda web tabanlı uzaktan eğitimin avantajlı olduğunu belirtmiştir. Odabaş (2003) internet tabanlı uzaktan eğitimin avantajları yanında dezavantajları olabileceğini ifade etmiştir. Web tabanlı uzaktan eğitim sisteminin gelişmesi için zamana ihtiyaç vardır ve tasarım, geliştirme ve bakım açısından bu sistem yüksek maliyete sahiptir. Öğreticilerin ve öğrencilerin bilgisayar kullanımında henüz yeterli düzeye ulaşmamış olmaması da dezavantajlarındandır. Uygulama yapmaya gereksinim duyulan konuların öğretiminde yaşanan zorluklar, bireysel çalışma alışkanlığı olmayan kişilerin yaşadığı sorunlar, uzun süreli bilgisayar kullanımı sonucunda yaşanan sağlı sorunları web tabanlı uzaktan eğitim sisteminde yaşanılabilecek olumsuz durumlardır.

Web tabanlı uzaktan eğitimde başarıyı getiren temel unsur; ileri teknolojinin sağlanmasından ziyade öğretici ve öğrenciler arasındaki iyi iletişim, öğrenciler arasındaki iş birliği, aktif öğrenme yöntemleri, ödevler ve projeler ile ilgili anında dönüt verme, öğrenciyi yönlendirebilme olmaktadır (Çağıltay, 2002). İnternet ve ileri teknoloji bunların sağlanmasında sadece rol oynamaktadırlar. Web tabanlı öğretimde iyi bir etkileşim ortamının oluşturulmasında öğretmenin uyması gereken bazı ilkeler, (Kaya, 2006) tarafından ifade edilmiştir. Bu ilkeler; öğretmenin teknolojik açıdan yeterli düzeyde bilgi sahibi olmasını, öğretmenin öğrenci ile etkili iletişim kurabilmesini ve öğretmenin öğrencilerin elinde olan teknolojik imkanlardan emin olmasını kapsamaktadır. Öğretmen ve öğrencilerin birbirlerini ekrandan görmelerinin telafisi yapılmalı, öğretmenler jest ve mimiklerine dikkat etmelidir. Öğretmenler öğrenci motivasyonunu artırılmalıdır.

Web tabanlı eğitimde iyi bir etkileşim ortamı eğitim kalitesinde önemli farklar oluşturacaktır. Nguyen ve Kulm (2005) web tabanlı uygulamanın, öğrencilerin öğrenme süreçleri üzerindeki etkilerini ve katkılarını geleneksel uygulamalarla karşılaştırdığı deneysel çalışmada web tabanlı öğrenme süreci geçiren grubun hem kesir hem de ondalık işlemler için daha iyi performans gösterdiği sonucuna ulaşmışlardır. Lin (2009) öğretmen adaylarının kesir bilgisine ilişkin web tabanlı öğretimin ve geleneksel öğretim yöntemlerinin karşılaştırmalı etkinliğini araştırmıştır. Deney ve kontrol gruplu deneysel desende yürütülen çalışmada öğretmen adaylarının kesir kavramları ile ilgili Web tabanlı kaynaklarla ders verdikleri zaman kavramsal anlayışlarını geliştirme firsatı sağladıkları ve etkili bir yöntem oluşturduğu sonucuna ulaşılmıştır. Diğer yandan, Web tabanlı eğitimde etkileşim ortamının iyi sağlanmadığı durumlarda da olumsuz yönde etkiler meydana gelecektir. Summerlin (2003) üniversite öğrencileri için internet tabanlı gelişimsel matematik öğretiminin akademik etkinliğini incelediği deneysel çalışmasında geleneksel yüz yüze eğitim yönteminin uygulandığ 1 kontrol grubu öğrencilerinin tamamına yakınının dersi tamamladığını, internet tabanlı eğitim yönteminin uygulandığı deney grubu öğrencilerinin ise büyük çoğunluğunun dersten ayrıldığını ve bu gruptaki başarısızlık oranının çok fazla olduğunu belirtmiştir.

Zaman ilerledikçe ve teknoloji geliştikçe eğitim içerisindeki teknolojinin rolü artmaktadır. Matematik eğitim-öğretim sürecini daha etkili hale getirmek için ders öğretim materyalleri olarak yazılımlar ve web siteleri geliştirilmekte 
ve kullanılmaktadır (Turgut ve Yenilmez, 2011). Bu tür yazılımlar ve web siteleri öğrenciler için kolaylaştırıcı pratik çalışmalar sağlar. Ayrıca eleştirel düşünce ve problem çözme becerilerini destekleyip geliştirir. $\mathrm{Bu}$ açılardan değerlendirildiğinde web tabanlı uzaktan eğitimin, matematik öğrenme-öğretme sürecinde olumlu etkiler göstereceği düşünülmektedir. Yorgancı (2013) senkron ve asenkron eğitim yöntemlerinin bütünleştirilmesiyle oluşturulan web tabanlı eğitim yönteminin öğrencilerin matematik başarılarına etkilerini ve web tabanlı matematik öğretimine ilişkin görüşlerini incelemiştir. Araştırma sonucunda web tabanlı matematik eğitimi uygulamasının öğrencilerin başarısını artırmada etkili bir yöntem olduğuna ulaşmıştır. Ayrıca web tabanlı öğrenme ortamının, zengin içerik, esneklik, bireysel öğrenmeye uygunluk ve zaman tasarrufu bakımından etkili bir yöntem olduğu öğrenci görüşleri Yorgancı (2014)'nın çalışmasında ortaya çıkmıștır. Ünal (2017) 5. sınıf fen bilimleri dersinde yer alan maddenin değişimi ünitesinin web tabanlı uzaktan eğitim ile öğretilmesinin öğrenci başarısına olan etkilerini araştırmak amacıyla yürüttüğü çalışmada web tabanlı uzaktan eğitimin öğrenciler üzerinde anlamlı bir farklılık yarattığı sonucuna ulaşmıştır. Orhan ve Men (2018), meta analiz yöntemi ile web tabanlı öğretimin öğrencilerin fen ders başarısı ve tutumlarına etkisini incelediği çalışmada olumlu yönde etkinin sonucuna ulaşmıştır. Özüsağlam (2007) ise internet tabanlı matematik dersinin nasıl anlatılacağına örnek olmasını amaçlayan bir ders sunum örneği hazırlamıştır ve çalışma sonunda web tabanlı öğrenme ile öğrencilerin matematik derslerinde eğlenerek öğreneceklerini belirtmiştir.

Web tabanlı uzaktan eğitim, özellikle örgün eğitimin sağlanamadığı durumlarda (hastalık, doğal afet, savaş vb.) kullanılabilecek bir alternatiftir. Geçirdiğimiz bu dönemde de ülkemiz ve dünya Covid-19 virüsü ile mücadele etmektedir. Bu zorlu süreçte okullara süresiz olarak ara verilmiştir. $\mathrm{Bu}$ süreç bizlere web tabanlı uzaktan eğitim sisteminin önemini göstermektedir. Gelişen teknoloji de web tabanlı öğrenme ortamlarını matematik eğitimi için daha somut, anlaşılır ve problem çözmeye uygun hale getirmiştir. Lin (2009), matematiksel kavramları yapılandırmada interaktif internet kaynakları yoluyla görsel modeller ve animasyon gösterimleri kullanımının önemli bir etkisinin olduğunu belirtmiştir. $\mathrm{Bu}$ sebeplerden dolayı matematik öğretmenlerinin web tabanlı uzaktan eğitim hakkındaki görüşlerini incelemek önemlidir. Bu çalışmanın, Covid-19 virüsünün dünyaya yayılmasıyla birlikte yeni bir yaşam tarzına büründüğümüz bu dönemde web tabanlı uzaktan eğitim ile ilgili önemli düşünceler ortaya koyacağı ve daha iyi bir web tabanlı uzaktan eğitim sistemi nasıl oluşturulur sorularına 1şık tutacağı düşünülmektedir. Ayrıca literatürde ortaokul matematik öğretmenlerinin web tabanlı uzaktan eğitim hakkındaki görüşlerini inceleyen çalışmaların azlığı da çalışmanın motivasyonunu oluşturan diğer bir unsurdur.

$\mathrm{Bu}$ çalışmanın amacı matematik derslerinde web tabanlı uzaktan eğitime ilişkin matematik öğretmenlerinin görüşlerini tespit etmektir. $\mathrm{Bu}$ amaçla aşağıdaki sorulara cevap aranmıştır:
1. Matematik öğretmenlerinin matematik eğitiminde web tabanlı uzaktan eğitime yönelik görüşleri nelerdir?

2. Matematik öğretmenlerinin web tabanlı uzaktan eğitim konusundaki önerileri nelerdir?

\section{Yöntem}

Bu bölümde çalışmanın deseni, çalışma grubu, veri toplama aracı, verilerin toplanması ve verilerin analizi konularında bilgiler verilmiştir.

\subsection{Araştırma Deseni}

$\mathrm{Bu}$ çalışmada matematik derslerinde web tabanlı uzaktan eğitimin kullanımıyla ilgili matematik öğretmenlerinin görüşlerini incelemek amaçlanmıştır. Çalışmanın deseni nitel araştırma yöntemlerinden fenomenolojidir. Fenomenolojik çalışma birden fazla kişinin bir fenomen (olgu) ile ilgili deneyimlerinin ortak algılarını keşfeder (Creswell, 2020). Bu çalışmada incelenen fenomeni "web tabanlı uzaktan eğitim" kavramı oluşturmaktadır. Matematik öğretmenlerinin web tabanlı uzaktan eğitim ile ilgili düşüncelerini, deneyimlerini ve önerilerini ortaya koyacak en iyi modelin fenomenoloji olacağı düşünülmüş ve çalışma bu modelde tasarlanmıştır. Ayrıca, yorumlayıcı fenomen deneyime yönelme ve yaşama ilişkin metinler yorumlama olarak tanımlandığından (Van Manen, 1990) çalışmada yorumlayıcı fenomenoloji benimsenmiştir. $\mathrm{Bu}$ yaklaşımda araştırmacılar ilk önce kendi ilgilerini çeken fenomene yönelmekte, ardından fenomen ile ilgili betimleme yapmaktadırlar (akt: Creswell, 2020).

\section{2. Çalıșma Grubu}

Çalışma grubunu farklı illerde ortaokul matematik öğretmenliği yapan 19 kişi oluşturmaktadır. Bu araştırmada maksimum çeşitlilik örneklemesi kullanılmıştır. $\mathrm{Bu}$ örneklem çeşidi nitel araştırmalarda oldukça yaygındır. $\mathrm{Bu}$ strateji oldukça farklılık gösteren mekanların veya katılımcıların seçimini içermektedir. Amaç farklı bakış açılarını yansıtma olasılığını artırmaktır (Creswell, 2020). Çalışma grubuna ait detaylı bilgiler Tablo 1'de verilmiştir:

Tablo 1. Katılımcıların Demografik Özellikleri

\begin{tabular}{|c|c|c|c|c|c|}
\hline Katılımc1 & Cinsiyet & Yaş & $\begin{array}{c}\text { Mesleki } \\
\text { deneyim } \\
(\mathrm{y} 1 \mathrm{l})\end{array}$ & $\begin{array}{c}\text { Katılımcının } \\
\text { Öğretmenlik } \\
\text { Yaptığı İl }\end{array}$ & $\begin{array}{c}\text { Katılımcının } \\
\text { Öğretmenlik } \\
\text { Yaptığı } \\
\text { Sinıf } \\
\text { Düzeyi }\end{array}$ \\
\hline Ö1 & $\mathrm{E}$ & 26 & 4 & Muş & $5 ., 6 ., 7 ., 8$. \\
\hline Ö2 & $\mathrm{K}$ & 29 & 7 & İstanbul & $6 ., 8$ \\
\hline Ö3 & $\mathrm{K}$ & 31 & 8 & İstanbul & $6 ., 7$. \\
\hline Ö4 & $\mathrm{K}$ & 27 & 5 & Samsun & 5., 6., 7., 8. \\
\hline Ö5 & $\mathrm{K}$ & 32 & 10 & İstanbul & 7., 8 . \\
\hline Ö6 & $\mathrm{E}$ & 27 & 6 & İstanbul & 7. \\
\hline Ö7 & $\mathrm{K}$ & 22 & 1 & İstanbul & $5 ., 6 .$, \\
\hline Ö8 & $\mathrm{E}$ & 33 & 7 & Erzurum & 8. \\
\hline Ö9 & $\mathrm{K}$ & 29 & 5 & Giresun & 5., 6., 7., 8., \\
\hline Ö10 & $\mathrm{E}$ & 28 & 3 & Şırnak & 6. \\
\hline Ö11 & $\mathrm{K}$ & 25 & 4 & Erzincan & 5., 6., 7., 8. \\
\hline Ö12 & $\mathrm{K}$ & 23 & 1 & İstanbul & $5 ., 6$. \\
\hline Ö13 & $\mathrm{K}$ & 27 & 4 & İstanbul & 5., 6., 7., 8., \\
\hline
\end{tabular}




\begin{tabular}{cccccc}
\hline Ö14 & E & 28 & 5 & Gaziantep & $7 ., 8$. \\
\hline Ö15 & K & 28 & 6 & İzmir & $5 ., 6 ., 7 ., 8 .$, \\
\hline Ö16 & E & 28 & 6 & İstanbul & $7 ., 8$. \\
\hline Ö17 & K & 23 & 1 & Tekirdağ & $6 ., 7 ., 8$. \\
\hline Ö18 & K & 23 & 1 & Tekirdağ & $5 ., 7 ., 8$. \\
\hline Ö19 & K & 27 & 4 & İstanbul & $5 ., 6 ., 7 ., 8 .$, \\
\hline
\end{tabular}

\section{Bulgular ve Yorumlar}

Bu bölümde verilerin analizi sonucu elde edilen bulgulara tablolarla ve alıntılarla yer verilmiştir ve bulgular yorumlanmıştır.

\subsection{Matematik Öğretmenlerinin Web Tabanlı Uzaktan} Eğitim Hakkındaki Düşünceleri

\subsection{Veri Toplama Araçları ve Verilerin Toplanması}

Bu çalışmada web tabanlı uzaktan eğitim ile ilgili matematik öğretmenlerinin görüşlerini almak amacıyla 8 adet açık uçlu soru bulunan yarı yapılandırılmış görüşme formu kullanılmıştır. Görüş̧e formunun hazırlanma sürecinde alanında uzman iki kişiye görüşme formundaki sorular incelettirilmiştir. Başlangıçta oluşturulan 7 açık uçlu sorudan birinin geniş kapsamlı olması sebebi ile uzmanların çıkarılmasına yönelik önerisi doğrultusunda görüşme formundan kaldırılmış ve bazı sorular dil bakımından düzeltilmiştir. Detaylı veri elde edebilmek için daha spesifik 2 yeni açık uçlu soru oluşturularak uygunluğu uzmanlarca teyit edildikten sonra görüşme formundaki sorulara son hali verilmiştir. Matematik öğretmenlerine uygulanan yarı yapılandırılmış görüşme formu Ek-2'de sunulmuştur.

Matematik öğretmenleriyle asıl görüşmeden önce ön görüşmeler yapılmış ve bu ön görüş̧mede amaçlanan çalışma hakkında bilgilendirilmişlerdir. Öğretmenler için uygun gün ve saat asıl görüşme için kararlaştırılmıştır. Görüşmeler öğretmenlerle telefon üzerinden gerçeklemiş ve yaklaşık 2030 dakika arasında sürmüştür. Konuşmaların hepsi katılımcıların izni alınarak kayıt cihazıyla kaydedilmiş̧ir. Yapılan görüşmelerde gönüllülük esas alınmıştır.

Araştırma ile ilgili İstanbul Üniversitesi Cerrahpaşa- Sosyal ve Beşeri Bilimler Araştırmaları Etik Kurulu'ndan 02/09/2020 tarih ve 2020/123 protokol numaras1 ile etik kurul uygunluk onayı alınmıştır.

\subsection{Veri Analizi}

Ortaokul matematik öğretmenlerinin web tabanlı uzaktan eğitim ile ilgili görüşlerini tespit etmek amacıyla yapılan görüşmelerden elde edilen veriler içerik analizi yöntemiyle analiz edilmiştir. Katılımcılara yöneltilen her sorunun cevabı derinlemesine incelenmiştir. Her cevap tekrar tekrar incelenmiş ve analiz sürecinde tümevarımsal analiz yöntemi benimsenmiştir. Önce kodlama ardından benzer kodların birleştirilmesiyle alt tema oluşturma ve son olarak alt temaları bir araya getiren temalar oluşturulmuştur. Veriler kodlanırken daha önceden belirlenmiş kavramlar ve verilerden çıkan kavramlar dikkate alınmıştır. Bu kodlama ile genel bir çerçeve içerisinde verilerin sunulması hedeflenmiştir. Veriler iki araştırmacı tarafından ayrı ayrı kodlanmış ve aralarındaki uyum yüzdesi $\% 92$ hesaplanmıştır. Kodlardaki anlaşmazlıkları çözmek için her iki araştırmacı da bir fikir birliğine varmak için farklılıkları tartı̧̧ıı̧̧ır.
Matematik Öğretmenlerin Web Tabanlı Uzaktan Eğitim Hakkındaki Düşünceleri web tabanlı uzaktan eğitim ile ilgili genel düşünceler, web tabanlı uzaktan eğitim ile ilgili deneyimler, web tabanlı uzaktan eğitimin matematik üzerindeki etkisi ve son olarak web tabanlı uzaktan eğitimin matematik açısından avantaj ve dezavantajları şeklinde 4 başlık altında incelenmiştir.

\section{Matematik Öğretmenlerinin Web Tabanlı Uzaktan Ĕ̈itim ile İlgili Genel Düşünceleri}

Bu bölümde matematik öğretmenlerinin web tabanlı uzaktan eğitim ile ilgili sahip oldukları genel düşüncelere yer verilmiştir. Yapılan analizler sonucu elde edilen kod ve temalara Tablo 2'de yer verilmiştir.

Tablo 2. Matematik öğretmenlerinin web tabanlı uzaktan eğitim hakkındaki düşünceleri

\begin{tabular}{|c|c|c|c|}
\hline Öğretmen & Kod & Alt Tema & Tema \\
\hline Ö4, Ö5, Ö6 & $\begin{array}{c}\text { İnternet altyap1 } \\
\text { yetersizliği }\end{array}$ & \multirow{2}{*}{$\begin{array}{c}\text { Alt yapının } \\
\text { yetersiz olması }\end{array}$} & \multirow{4}{*}{ 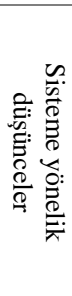 } \\
\hline Ö4, Ö14, Ö10 & $\begin{array}{c}\text { İnternet erişimine } \\
\text { yönelik yetersizlikler }\end{array}$ & & \\
\hline Ö15 & $\begin{array}{l}\text { Etkinlik kaynağı } \\
\text { yetersizliği }\end{array}$ & \multirow{2}{*}{$\begin{array}{c}\text { Kaynakların } \\
\text { yetersiz olması }\end{array}$} & \\
\hline Ö6 & $\begin{array}{c}\text { Her öğrenci için } \\
\text { teknolojik imkanların } \\
\text { yeterli olmaması }\end{array}$ & & \\
\hline Ö8 & $\begin{array}{l}\text { Öğrencinin çabuk } \\
\text { adapte olması }\end{array}$ & \multirow{6}{*}{$\begin{array}{c}\text { Öğrenci-öğretmen } \\
\text { iletişimi }\end{array}$} & \multirow{6}{*}{ 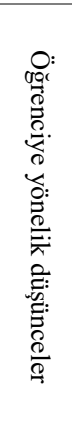 } \\
\hline Ö6 & $\begin{array}{c}\text { Öğrencinin } \\
\text { motivasyon kaybı }\end{array}$ & & \\
\hline Ö1 & $\begin{array}{c}\text { Öğrencilerin rahat } \\
\text { olması }\end{array}$ & & \\
\hline Ö13, Ö17 & $\begin{array}{c}\text { Öğrenci kontrolünün } \\
\text { yapılamaması }\end{array}$ & & \\
\hline Ö3, Ö6 & $\begin{array}{l}\text { Öğrenci-öğretmen } \\
\text { iletişiminin iyi } \\
\text { olmaması }\end{array}$ & & \\
\hline Ö13 & $\begin{array}{l}\text { Öğrenci-öğretmen } \\
\text { iletişimi sağlaması }\end{array}$ & & \\
\hline Ö4, Ö19 & $\begin{array}{l}\text { Web tabanlı uzaktan } \\
\text { eğitimin gerekliliği }\end{array}$ & \multirow{7}{*}{ değerlendir } & \multirow{7}{*}{ 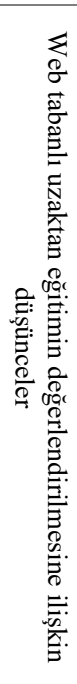 } \\
\hline Ö1, Ö6, Ö19 & $\begin{array}{l}\text { Web tabanlı uzaktan } \\
\text { eğitimin zaman } \\
\text { tasarrufu sağlaması }\end{array}$ & & \\
\hline Ö6 & $\begin{array}{l}\text { Web tabanlı uzaktan } \\
\text { eğitimin ekonomik } \\
\text { olması }\end{array}$ & & \\
\hline $\begin{array}{l}\text { Ö5, Ö3, Ö16, } \\
\text { Ö1, Ö7, Ö12 }\end{array}$ & $\begin{array}{c}\text { Web tabanlı uzaktan } \\
\text { eğitimin faydalı } \\
\text { olması }\end{array}$ & & \\
\hline Ö19, Ö6 & $\begin{array}{l}\text { Web tabanlı uzaktan } \\
\text { eğitimin zamandan ve } \\
\text { mekândan bağımsız } \\
\text { olması }\end{array}$ & & \\
\hline Ö12 & $\begin{array}{c}\text { Web tabanlı uzaktan } \\
\text { eğitimin firsat eşitliği } \\
\text { sağlaması }\end{array}$ & & \\
\hline Ö9, Ö17 & $\begin{array}{l}\text { Web tabanlı uzaktan } \\
\text { eğitimin iyi bir } \\
\text { alternatif olması }\end{array}$ & & \\
\hline
\end{tabular}




\begin{tabular}{|c|c|c|c|}
\hline Ö8, Ö9 & $\begin{array}{l}\text { Web tabanlı uzaktan } \\
\text { eğitimin başarılı } \\
\text { olması }\end{array}$ & & \\
\hline Ö16 & $\begin{array}{l}\text { Web tabanlı uzaktan } \\
\text { eğitimin deneyim } \\
\text { sağlaması }\end{array}$ & & \\
\hline Ö8 & $\begin{array}{l}\text { Web tabanlı uzaktan } \\
\text { eğitimin fena } \\
\text { olmaması }\end{array}$ & \multirow{5}{*}{$\begin{array}{c}\text { Olumlu veya } \\
\text { olumsuz olarak } \\
\text { nitelendirilemeyen } \\
\text { değerlendirmeler }\end{array}$} & \\
\hline $\begin{array}{l}\text { Ö4, Ö15, Ö17, } \\
\text { Ö11 }\end{array}$ & $\begin{array}{l}\text { Web tabanlı uzaktan } \\
\text { eğitim mecbur } \\
\text { kalınan bir eğitim } \\
\text { türü olması }\end{array}$ & & \\
\hline Ö8, Ö17 & $\begin{array}{l}\text { Web tabanlı uzaktan } \\
\text { eğitimin hiç yoktan } \\
\text { iyi olması }\end{array}$ & & \\
\hline Ö10 & $\begin{array}{l}\text { Web tabanlı uzaktan } \\
\text { eğitimin batıda } \\
\text { uygulanabilir olması } \\
\text { fakat doğuda } \\
\text { uygulanabilir } \\
\text { olmaması }\end{array}$ & & \\
\hline Ö6 & $\begin{array}{l}\text { Web tabanlı uzaktan } \\
\text { eğitimin örgün } \\
\text { eğitimi desteklerse } \\
\text { faydalı olması }\end{array}$ & & \\
\hline Ö6 & $\begin{array}{l}\text { Öğretmenler için yeni } \\
\text { bir deneyim } \\
\text { kazandırması }\end{array}$ & \multirow{2}{*}{$\begin{array}{l}\text { Öğretmene } \\
\text { etkileri }\end{array}$} & \multirow{2}{*}{ 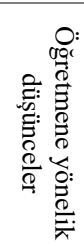 } \\
\hline Ö18 & $\begin{array}{l}\text { Öğretmenlerde } \\
\text { teknolojik kimlik } \\
\text { oluşturması }\end{array}$ & & \\
\hline
\end{tabular}

Elde edilen tema ve kodlar matematik öğretmenlerinin web tabanlı uzaktan eğitimi farklı bakış açıları ile ele aldıklarını göstermiştir. Sisteme yönelik düşünceler teması öğretmenlerin içinde bulundukları sisteme yönelik algılarını ortaya koymaktadır. İnternete erişim ve kaynaklar konusunda yaşanan aksaklıklar sebebiyle öğretmenlerin bu temaya yönelik algıları daha çok olumsuz olmuştur. Örneğin Ö14 "Uzaktan eğitim güzel bir uygulama, yalnız şu an ortam olarak, ülke olarak buna uygun değiliz. Mesela öğrencilerin internete ulaşması sinırll, yok denecek kadar az" şeklinde düşüncesini açıklarken Ö6 kodlu öğretmen “ $B i z$ ögrretmenler olarak ne düşünüyoruz biraz onlardan bahsedeyim. Sinırlılıklarl mesela öncelikle öğrencilerin hepsinin elinde internet bağlantısı veya bilgisayar tablet gibi teknolojik aletler yok. Bu ögrenciler bir kere derse katılamazlar" şeklinde yaşanabilecek zorluktan bahsederek web tabanlı uzaktan eğitimi sistemin yetersizliği üzerinden yorum yapmıştır. Öğretmen görüşleri doğrultusunda sistemde yaşanan sıkıntıların web tabanlı uzaktan eğitime yönelik düşünceler üzerinde önemli bir etkiye sahip olduğu görülmektedir. $\mathrm{Bu}$ etkinin sebebi ise web tabanlı uzaktan eğitim sistemini meydana getiren araçların başında internet ve internet üzerindeki kaynakların gelmesidir.

Öğretmenler öğrenci açısından da web tabanlı uzaktan eğitimi ele almış ve fikirlerini sunmuşlardır. Öğrenciye yönelik düşünceler temasında toplanan bu fikirler incelendiğinde öğrencilerin yaşayacağı olumlu veya olumsuz durumların öğretmenlerin web tabanlı uzaktan eğitimi değerlendirirken dikkat ettiği hususlar olduğu görülmektedir. Ö8 kodlu öğretmen "Önceden kullanmamamıza răgmen öğrenciler, ögretmenlerden çabuk adapte oldular" şeklinde olumlu durumu; Ö13 kodlu öğretmen "Bütün öğrencilerle iletişim sağlayamadık kontrollerini de çok fazla yapamıyoruz. EBA üzerinden yapılan ödevlendirmelerde görüyoruz kimin ne yapıp yapmadı̆̆ını ama çocuk üzerinde bir etkimiz olmuyor. Tabii ki ödevlendirme, konu anlatımı, canlı dersler bunlar güzel olanaklardı fakat dediğim gibi her ögrenci üzerinde de etkili olamadık maalesef o kontrol açısından" şeklinde olumsuz durumu dikkate alarak öğrenciler açısından düşüncelerini ifade etmişlerdir. Öğretmenler için web tabanlı uzaktan eğitim sistemini oluşturan en önemli unsurun öğrenciler olması ve bu konuda edindikleri deneyimler sonucu öğretmenlerin öğrenciler açısından oluşan düşüncelere yer verdikleri düşünülmektedir.

Aynı zamanda öğretmenler web tabanlı uzaktan eğitimi olumlu, ne olumlu ne olumsuz ve olumsuz olarak değerlendirmiş ve düşüncelerini ifade etmişlerdir. $\mathrm{Bu}$ değerlendirmeler web tabanlı uzaktan eğitimin değerlendirilmesine ilişkin düşünceler teması altında toplanmıştır. Burada öğretmenlerin en çok olumlu değerlendirme yaptıkları dikkat çekmiştir. Özellikle 6 öğretmen faydalı olarak web tabanlı uzaktan eğitimi nitelendirmiştir. Örneğin Ö5 kodlu öğretmen “... web tabanl uzaktan eğitimin aslında çok yararlı olduğunu ve çok gerekli olduğunu da gördük" şeklindeki ifadesi ile bunu göstermiştir. Öğretmenlerin web tabanlı uzaktan eğitimin asla örgün eğitimin yerini tutmaması üzerine ifade ettikleri olumsuz değerlendirmelerinin sebebinin öğretmenlerin web tabanlı uzaktan eğitimi bir alternatif sistem olarak değil kendi başına oluşacak bir eğitim sistemi olarak ele almaları olduğu düşünülmektedir. Yerine alma ifadesinin kullanılması bunu göstermektedir. Örneğin Ö17 kodlu öğretmen "Hiç yoktan iyidir diye düşünüyorum. Özellikle şu dönemde. Ama tabii ki yüz yüze ĕgitimin yerini asla tutmuyor, tabii ki çocukların şu an şu dönemde hiçbir şey görmemelerindense bu şekilde olması da iyi oldu" demiştir.

Öğretmenlerin genel düşünceler başlığı altında son olarak bir öğretmen bakış açısını yansıttıkları düşünceleri öğretmene yönelik düşünceler teması altında toplanmıştır. Öğretmenler öğrenciler gibi web tabanlı uzaktan eğitim sistemi içerisinde yer alan önemli unsurlardır. Ö18 kodlu öğretmen “.... süreci çok iyi yöneten ögrretmenler de vardl. Özellikle teknolojik kimliği olan öğretmenler gerçekten diğer öğretmenlere ve ögrencilere de çok yardımcı oldular” ve “...bu uzaktan eğitim süreci her öğretmenin teknolojik kimliğinin olmasi gerektiğini en çarpıcı şekilde gösterdi" şeklindeki ifadeleri ile bu görüşü desteklemiştir.

Matematik öğretmenlerinin web tabanlı uzaktan eğitim ile ilgili sahip oldukları genel düşünceler incelendiğinde öğretmenlerin web tabanlı uzaktan eğitimin her bir parçası için düşüncelerini dile getirdikleri görülmüştür. Öğretmenler web tabanlı uzaktan eğitimi daha çok olumlu değerlendirmişlerdir. İnternete erişim ve alt yapı problemleri öğretmenlerin üzerinde durdukları konulardır. Dolayısıyla bu problemlerin giderilmesi web tabanlı uzaktan eğitimin etkililiği açısından önemlidir. 


\section{Matematik Öğretmenlerinin Web Tabanlı Uzaktan Ĕgitim ile İlgili Deneyimleri}

Bu bölümde matematik öğretmenlerinin web tabanlı uzaktan eğitim ile ilgili sahip oldukları deneyimlere ve bu deneyimleri nasıl yorumladıklarına yer verilmiştir. Öğretmen görüşleri dikkate alındığında Covid-19 virüsü sebebiyle yaşanan pandemi sürecinin Türkiye'deki etkisi görülmüştür. $\mathrm{Bu}$ süreçte örgün eğitim sekteye uğramış ve uzaktan eğitim süreci ile eğitim devam ettirilmek istenmiştir. Öğretmenler de web tabanlı uzaktan eğitim ile ilgili deneyimlerini anlatırken daha çok bu süreci baz almış ve bu süreç içerisinde yaşadıklarını araştırmacıya aktarmıştır. Veri analizleri sonucu elde edilen kod, alt tema ve temalara Tablo 3' de verilmiştir.

Tablo 3. Matematik öğretmenlerinin web tabanlı uzaktan eğitim deneyimler

\begin{tabular}{|c|c|c|c|}
\hline Öğretmen & Kod & Alt Tema & Tema \\
\hline Ö1, Ö10 & $\begin{array}{c}\text { Youtube'a videolar } \\
\text { çekmek }\end{array}$ & \multirow{3}{*}{$\begin{array}{l}\text { Sosyal medya } \\
\text { üzerinden web } \\
\text { tabanlı uzaktan } \\
\text { eğitim deneyimi }\end{array}$} & \multirow{8}{*}{ 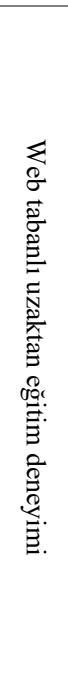 } \\
\hline $\begin{array}{l}\text { Ö1, Ö7, } \\
\text { Ö10, Ö16, } \\
\text { Ö18 }\end{array}$ & $\begin{array}{l}\text { Whatsapp üzerinden } \\
\text { paylaşım }\end{array}$ & & \\
\hline Ö10, & $\begin{array}{c}\text { Instagram üzerinden canlı } \\
\text { yayın }\end{array}$ & & \\
\hline $\begin{array}{c}\text { Ö2, Ö3, } \\
\text { Ö7, Ö8, } \\
\text { Ö11, Ö12, } \\
\text { Ö17, Ö18, } \\
\text { Ö19 }\end{array}$ & EBA & \multirow{3}{*}{$\begin{array}{c}\text { Web sitesi } \\
\text { üzerinden web } \\
\text { tabanlı uzaktan } \\
\text { eğitim deneyimi }\end{array}$} & \\
\hline Ö15 & E dergi & & \\
\hline $\begin{array}{l}\text { Ö7, Ö8, } \\
\text { Ö14, Ö16, } \\
\text { Ö17 }\end{array}$ & Zoom & & \\
\hline Ö19 & Üniversite dersleri & \multirow{2}{*}{$\begin{array}{l}\text { Öğretmenin } \\
\text { kendi eğitimi } \\
\text { için olan web } \\
\text { tabanlı uzaktan } \\
\text { eğitim deneyimi }\end{array}$} & \\
\hline Ö15, Ö19 & Seminer & & \\
\hline
\end{tabular}

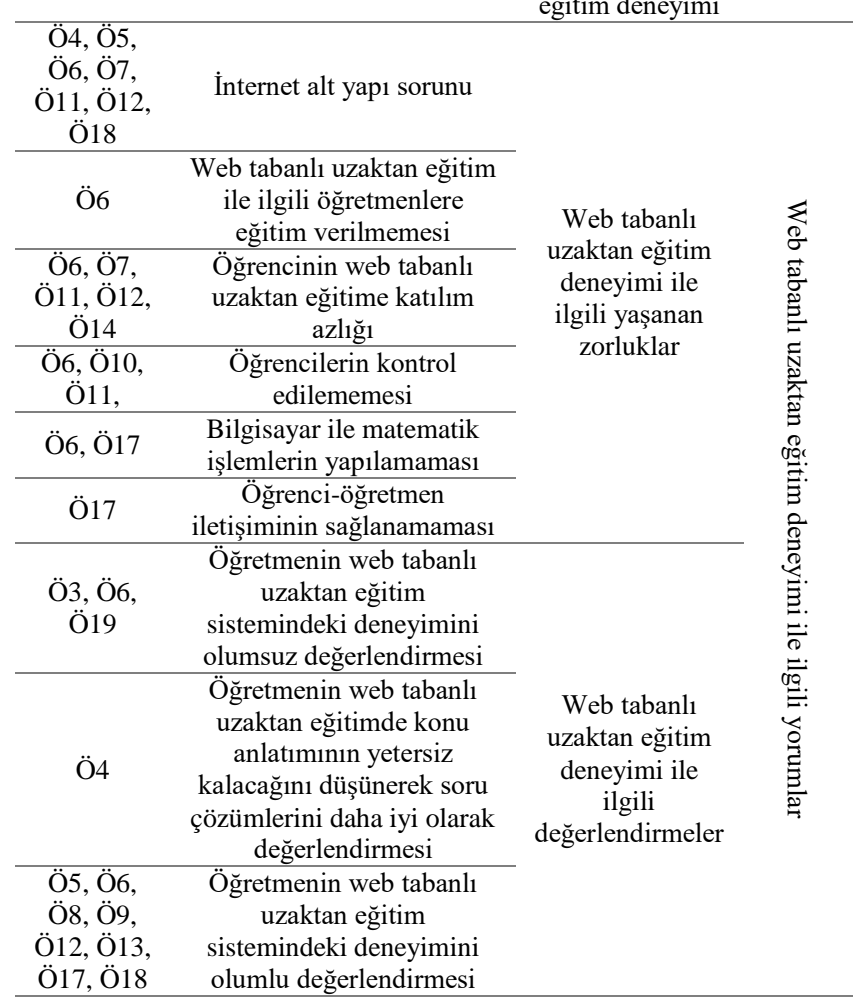

Matematik öğretmenlerinin yaşadığı deneyimler sosyal medya ve web siteleri üzerinden gerçekleşmiștir. Örneğin Ö1 kodlu öğretmen "Ben şahsen YouTube üzerinden uzaktan eğitimi baz alarak videolar çekiyorum bu konuda deneyimli hissediyorum" demiştir. Benzer şekilde Ö10 kodlu öğretmen “... okula ait bir Instagram hesabı açtım. Akşamları canlı yayın açıp onların sorduğu soruların çözümlerini yaptık daha önceden topladığımız soru havuzundan" demiştir. Ö18 kodlu öğretmen ise "Ben EBA'ya ilk kez bu uzaktan eğitim sürecinde girmeyi denedim. Illk defa o zaman girdim. EBA nedir ne işe yarar hiçbir şekilde deneyimim yoktu ancak uzaktan eğitim geldi ve EBA'y öğrendim araştırdım videolar izledim" demiştir. Ö18 kodlu öğretmenin deneyimini kazanmada zorunlu bir durum içerisinde bulunmasının etkisi olduğu görülmüştür. Öğretmenlerin çoğu pandemi dolayısıyla zorunlu olarak geçilen uzaktan eğitim sürecinde Zoom platformu üzerinden canlı ders yapma deneyimini yaşamışlardır. Zoom ile yaşanan deneyimi Ö18 kodlu öğretmen "Bunu en çok ben kullandım. İlk başlangıçta, EBA'daki derslerden de önce, karantina sürecinde Zoom'dan dersleri başlatmıştım ben. Güzel de oldu, hatta birçok ilgisiz olan ögrenci de ilgi göstermiş oldu. Farklı geldi yani" şeklinde ifade etmiştir.

Matematik öğretmenleri deneyimlerini yorumlarken ise yaşadıkları zorluklardan yola çıkmışlardır ve deneyimlerini değerlendirirken çıkarımda bulunmuşlardır. Bu ifadeler iki alt tema halinde toplanmıştır. Burada en çok dikkati öğretmenlerin web tabanlı uzaktan eğitim ile ilgili deneyimlerini olumlu değerlendirmeleri olmuştur. 8 öğretmen bu yorumda bulunmuştur. Örneğin Ö9 kodlu öğretmen "Ben kendim yüksek lisans eğitiminde ögrenci olarak ve Milli Eğitim'de de ögretmen olarak uzaktan eğitim Web tabanlı eğitimin kullanıcısıyım. Tabii ki dezavantajları var ama hem ögretmen hem öğrenci açısından rahatlık olduğunu düşünüyorum. Matematikte ders anlatırken ögrencilerde kopmalar olabiliyordu diğer öğrencilerin dikkatini toplamak zorlaşabiliyordu burada sinıf hakimiyeti kurmak zorunda olmamak bence ögretmen açısından büyük bir enerji tasarrufu diyebilirim" şeklinde deneyimini yorumlamıştır. Öğretmenlerin web tabanlı uzaktan eğitimde yaşadıkları deneyimleri yorumlarken zorlandıkları kısımları ifade etmişlerdir. Özellikle öğretmenlerin yaşadığı teknik sıkıntılar deneyimleri yorumlarken etkili olmuştur. Ayrıca öğretmenler en çok öğrenci ile olan iletişim ve öğrenci katılımına önem vermiştir. Bu duruma örnek olarak Ö11 kodlu öğretmenin "...canlı derslere katılım sayısı az olabiliyor, canlı dersin verimli olmayacă̆ını öğretmenle birebir etkileşimle olmayacağını düşünüyor çocuklar. O yüzden sisteme girmeyebiliyorlar. Ya da bu sürecin (pandemi) ilk başında okulların tatil edilmesi diye söylendiğ $i$ için öğrenci zaten eğitim ortamından kopmuş durumda o yüzden tekrardan sisteme gireyim canlı ders alayım ya da EBA üzerinden ben online olarak derslerime devam edeyim düşüncesinde değiller" ifadeleri örnek gösterilebilir. Burada Ö11 kodlu öğretmenin yaşadığı zorluğun asıl sebebi öğrencilerin web tabanlı uzaktan eğitim sürecini önemsememelerinden kaynaklanmaktadır. 
Matematik öğretmenleri web tabanlı uzaktan eğitim deneyimlerini çeşitli platformlar üzerinden yaşamışlardır. Öğretmenler bu deneyimlerinde en çok öğrencilerin derslere katılım sayılarının az olması konusunda zorluk yaşamışlardır. Bu durum internete erişimi olmayan ve tablet, bilgisayar gibi teknolojik araçlardan uzak öğrencilerin eksiklerinin giderilmesi ihtiyacına işaret etmektedir.

\section{Matematik Öğretmenlerinin Web Tabanlı Uzaktan Ĕ̈itimin Matematik Üzerindeki Etkisi ile İlgili Düşünceleri}

Bu bölümde matematik öğretmenlerinin web tabanlı uzaktan eğitimin matematik üzerindeki etkisi ile ilgili düşüncelerine yer verilmiştir. Yapılan analizler sonucu elde edilen kod ve temalara Tablo 4'de yer verilmiştir.

Tablo 4. Matematik öğretmenlerinin web tabanlı uzaktan eğitimin matematik öğrenme-öğretme sürecindeki etkilerine yönelik görüşleri

\begin{tabular}{|c|c|c|}
\hline Öğretmen & Kod & Tema \\
\hline Ö4, Ö6, Ö17 & $\begin{array}{c}\text { Öğrencinin matematik } \\
\text { derslerinde dinleyici rolünde } \\
\text { olması }\end{array}$ & \multirow{3}{*}{ 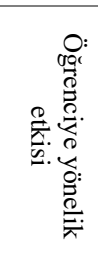 } \\
\hline Ö9 & $\begin{array}{c}\text { Matematik korkusu yaşayan } \\
\text { öğrencilerin daha rahat } \\
\text { olması }\end{array}$ & \\
\hline Ö6 & $\begin{array}{c}\text { Öğrenciler arası iyi } \\
\text { iletişiminin olmaması }\end{array}$ & \\
\hline Ö1, Ö18 & $\begin{array}{c}\text { Öğretmenin aktif öğrenme } \\
\text { yöntemlerini } \\
\text { uygulayamaması }\end{array}$ & \multirow{5}{*}{ 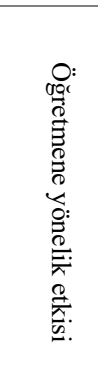 } \\
\hline Ö13, Ö14 & $\begin{array}{l}\text { Öğretmenin matematikteki } \\
\text { sayısal işlemleri yaparken } \\
\text { bilgisayarda yașadığı zorluk }\end{array}$ & \\
\hline Ö14 & $\begin{array}{c}\text { Öğretmenin somut materyal } \\
\text { sunamaması }\end{array}$ & \\
\hline Ö6, Ö10, Ö16, Ö17 & $\begin{array}{l}\text { Öğretmenin öğrencileri } \\
\text { kontrol edememesi }\end{array}$ & \\
\hline Ö19 & $\begin{array}{l}\text { Öğretmenin öğrencileri } \\
\text { kontrol edebilmesi }\end{array}$ & \\
\hline Ö18 & $\begin{array}{c}\text { Öğrenciye anında dönüt } \\
\text { verememek }\end{array}$ & \multirow{3}{*}{ 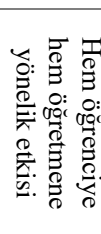 } \\
\hline Ö6, Ö12, Ö16 & $\begin{array}{c}\text { Öğretmenin öğrencinin dersi } \\
\text { anlayıp anlamadığını } \\
\text { anlayamaması }\end{array}$ & \\
\hline Ö13, Ö16, Ö17 & $\begin{array}{l}\text { Öğrenci-öğretmen } \\
\text { iletişiminin az olması }\end{array}$ & \\
\hline Ö18 & $\begin{array}{l}\text { Görsel materyallerin } \\
\text { kullanılması }\end{array}$ & \multirow{3}{*}{ 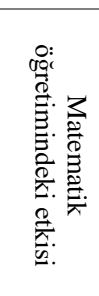 } \\
\hline Ö7, Ö18 & $\begin{array}{c}\text { Örgün eğitimin olmadığı } \\
\text { durumlarda matematik } \\
\text { öğretiminin devamını } \\
\text { sağlama }\end{array}$ & \\
\hline $\begin{array}{l}\text { Ö5, Ö7, Ö10, Ö11, } \\
\text { Ö15, Ö17, Ö19 }\end{array}$ & $\begin{array}{l}\text { Web tabanlı uzaktan eğitimin } \\
\text { matematik ögrretiminde etkili } \\
\text { ve verimli olamaması }\end{array}$ & \\
\hline
\end{tabular}

Matematik öğretmenleri web tabanlı uzaktan eğitimin matematik öğrenme-öğretme sürecindeki etkilerini göz önüne aldıklarında bazı öğretmenler sadece öğrenciler, bazı öğretmenler sadece öğretmenlere, bazıları ise hem öğrenci hem öğretmen açısından durumu değerlendirmişlerdir. Bunlara ek olarak bir kısım öğretmen ise web tabanlı uzaktan eğitimin matematik öğretimindeki etkisini ifade etmiştir. Matematik dersleri daha çok zor ve anlaması güç bir ders olarak algılanmaktadır. Bunun önüne geçmek adına öğretmenler öğrencilerin aktif rol oynamasını önemsemektedir. Örneğin Ö4 kodlu öğretmen "Matematik üzerine etkilerine gelecek olursak web tabanl uzaktan eğitimin, matematik ĕgitiminde biliyorsunuz öğrenciye gösterip yaptırtma tarzl özellikle ögrencinin aktif olduğu yöntemlerde daha çok başar sağllyoruz fakat uzaktan eğitimde öğrenciler çok fazla aktif olamıyorlar” şeklindeki ifade ile öğrencileri aktif kılamadığı bir eğitim ortamı olan web tabanlı uzaktan eğitimi olumsuz değerlendirmiştir. Buna ek olarak Ö9 kodlu öğretmen ise matematik korkusu yaşayan öğrencilerin web tabanlı uzaktan eğitim sürecinde daha rahat olacağını savunmuş ve şu şekilde ifade etmiştir: "Matematik ögrretimine katkısı olarak ögrencilerin derse daha odaklanabildiğini evlerinde kendilerini rahat hissettiğ $i$ bir ortamda görmeleri sağlanmış oldu. Öğrenciler zaten matematiğe önyargılı bazıları arkadaşlarından çekiniyorlar tahtaya çıkma fobisi vard. Bunlar engellenmiş oldu daha rahat bir süreç yaşamış oldular”. Ö6 kodlu öğretmen ise “... ögrenciye uzaktan ĕgitimde arkadaşların da olumlu hiçbir etkisi olamıyor yani sınıftaki gibi ufak böyle küçük tatl rekabetler, onlart teşvik edecek ufak böyle yarışmalar, heyecanlandırıcı küçük etkinlikler bunların hiçbirisini yapamıyoruz" şeklindeki açıklaması ile aslında aynı fiziksel ortam içerisinde bulunan öğrencilerin daha olumlu davranışlar sergileyeceğini savunmuştur. Öğretmene yönelik etkilerini tartışan öğretmenlerin çoğunun öğrencileri kontrol etme eyleminde zorlandıkları görülmüştür. Ö17 kodlu öğretmen "Bizim ögretmenlik yaptığımız ögrrenci grubu küçük yaşta oldukları için elimiz üzerinde olması gerekiyor. Yani tamamen sorumluluklarını alamıyorlar. Genelde kızlar daha iyi ama erkekler kesinlikle üzerinde olacak elimiz. Ben bu dönemde öğrencilerle çok uğraştım. Ama yapacak bir şey olmuyor görmüyorum ki, soruma da cevap vermeyenler oldu, ben daha ne yapabilirim. Bu uzaktan eğitim isteyen öğrenciler de işe yaradı istemeyen ögrenciler tamamen uzak kaldı" demiştir.

Öğretmenler aynı zamanda matematik dersi anlatım aşamasında da zorlanmışlardır. Özellikle bunun sebebi bilgisayar ile sayısal işlemlerin yapılma zorluğundan gelmektedir. Ö14 kodlu öğretmen bu durumu şu şekilde açıklamıştır: "Matematik genellikle işleme dayalı olduğu için uzaktan eğitimde öğrencilere işlemleri gösterme konusunda bilgisayarda yazarken zorluk yaşayabiliyoruz. Dokunmatik ekranlı laptoplar olduğu zaman bir sıkıntı olmayacak ama ögrencilere bazl bilgileri aktarmakta zorluk yaşlyoruz bilgisayarda. Soyut olduğu için matematik her şeyi öyle düz anlatımla geçiştiremiyoruz. Sayıları ögretmemiz lazım şekilleri göstermemiz lazım. Çocukların kafasında somutlaştırmak için bazı şeyler yapmamız lazım. Onlar içinde bazı zorluklar yaşıyoruz”. Öğrenci-öğretmen arasında yaşanan iletişim matematik öğrenme ve öğretme sürecinde oldukça önemlidir. İyi bir iletişim beraberinde olumlu davranışlar getirmekte bunun aksine kötü bir iletişim ise problem oluşturmaktadır. Öğretmenler iletişim açısından web tabanlı uzaktan eğitimin matematik üzerindeki etkisini yorumladıklarında olumsuz olarak değerlendirmişlerdir. Öğrencilere anında dönüt verememek, öğrencilerin dersi anlayıp anlamadıklarını anlayamamak ve iletişimin az olması web tabanlı uzaktan eğitim ile birlikte yaşanan 
olumsuz durumlar olarak öğretmenler tarafindan ifade edilmiştir. Örneğin Ö12 kodlu öğretmen "Normalde matematik gibi bir derste ögrencilerin surat ifadelerinden anlayıp anlamadıklarını, derse olan ilgilerini çok rahat anlayabiliyoruz. Ama uzaktan eğitimle böyle bir şey söz konusu olmuyor. Özellikle kalabalık siniflarda zaten bunu fark etmek çok daha zorlaşlyor. O sebeple şunu söyleyebilirim ögrencilerin ögrenip ögrrenmediklerini fark etme noktasında bir sıkıntı oluyor" demiştir. Benzer şekilde Ö14 kodlu öğretmen ise "Çocukla bir etkileşimim yok. Yani sadece ekrandan olduğu kadar. Bir de MEB'de bazı şeyler yaylldı, çocuklara sesinizi, ekraninızı kapatın denildi. Bu sefer biz iletişimde bulunamadik çocuklarla. Soru soruyoruz yasak koydular. Ekraninızı açmayın. Ben çocuğu göremiyorum. Ben normalde okulda çocuğun gözünden anliyorum anlayıp anlamadığını ama burada anlamıyorum. Çocuğa soru soruyorum mikrofonunu açıp soruya cevap verene kadar burada rahat geri dönütler alamiyorum. Bu sefer ben duvara mi anlatiyorum demeye başladım bazı derslerde." demiştir.

Matematik öğretimindeki etkisi incelendiğinde 7 öğretmenin web tabanlı uzaktan eğitimin matematik üzerinde yetersiz ve verimsiz etkisi olduğu görüşüne sahip oldukları dikkat çekmektedir. Ö10 kodlu öğretmen "Ben genelde derslerime gülerek eğlenerek yapmaya çalışırım, çok fazla bağırmak istemiyorum. Çocuğu frenleyecek değil de daha çok bak hadi tamam eğlenelim gülelim 5 dakika onu yapalım kalan 20 dakikada ders yapalım tarzında gittiğim için interaktif ortamda matematik biraz daha zor oluyor. Matematik yüz yüzeyken daha iyiymiş gibi geliyor bana. Çünkü çocukları da bir noktada motive etmek gerekiyor ama web tabaninda motive etmek çok zor" demiştir. Burada Ö10 kodlu öğretmenin matematik üzerindeki etkisinden ziyade öğrenci üzerindeki etkisine değindiği düşünülmüştür. Fakat matematik dersi içerisinde yer alan öğrenci üzerinde etkisiz kalmış web tabanlı uzaktan eğitimin asıl matematik öğretimini etkilediği şeklinde yorumlanmıştır. Ö18 kodlu öğretmen ise web tabanlı uzaktan eğitimin matematik üzerindeki olumlu etkisine değinmiştir. Bu etkinin nedeni görsel materyal sunabilme imkânı sağlayabilmesidir. Ö18 kodlu bu öğretmenin bu görüşe sahip olma nedeni fiziksel okul ortamının teknolojik imkanlar konusunda eksik olmasıdır. Bu durum öğretmen tarafından şu şekilde ifade edilmiştir: "En büyük anlamda olumlu etkileri bizim okullarımızda akıllı tahta olmadığı için fazla görsel materyal falan paylaşamıyorduk. Ama uzaktan eğitim sürecinde, EBA' da çok zengin içerikler var ya da Youtube'dan videolar falan paylaşlyoruz".

Matematik öğretmenleri web tabanlı uzaktan eğitimin matematik üzerindeki etkisini öğrenci, öğretmen, hem öğrenci hem öğretmen ve matematik öğretimi açısından değerlendirmişlerdir. Öğrenci-öğretmen arasındaki iletişim öğretmenlerin çoğunun fikir sunduğu konu olmuştur. Çünkü etkili bir iletişimin matematik öğretiminde olumlu etki gösterdiğini düşünmektedirler. Bu sebeple öğrenci-öğretmen iletişimini web tabanlı uzaktan eğitim sisteminde de sağlayacak dijital ortamların kullanımı yaygınlaştıılmalıdır.

\section{Matematik Öğretmenlerinin Web Tabanlı Uzaktan Ĕ̈itim Açısından Avantaj ve Dezavantajlarına Yönelik Düşünceleri}

Bu bölümde matematik öğretmenlerinin web tabanlı uzaktan eğitimin matematik öğrenme ve öğretme süreci açısından avantaj ve dezavantajlarını ifade ettikleri düşüncelere yer verilmiştir. Öğretmenler matematik öğrenme-öğretme sürecindeki web tabanlı uzaktan eğitimin avantajlarını ve dezavantajlarını değerlendirirken içinde bulundukları pandemi döneminin etkileri görülmüştür. Fakat bu durum web tabanlı uzaktan eğitim için genellenebilir durumdadır. Yapılan analizler sonucu elde edilen kod ve temalar iki tablo halinde verilmiştir. Tablo 5'de avantajlar, Tablo 6'da dezavantajlar olarak öğretmen görüssleri iki bölüm altında incelenmiştir.

Tablo 5. Matematik öğretmenlerinin web tabanlı uzaktan eğitimin matematik öğrenme-öğretme sürecindeki avantajlarına yönelik görüşleri

\begin{tabular}{|c|c|c|}
\hline Öğretmen & Kod & Tema \\
\hline Ö6, Ö8, Ö9 & $\begin{array}{c}\text { Öğrencilerin aynı } \\
\text { matematik } \\
\text { derslerini tekrar } \\
\text { tekrar dinleyebilme } \\
\text { avantajı }\end{array}$ & \multirow{3}{*}{ 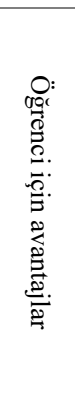 } \\
\hline Ö4, Ö18, Ö19 & $\begin{array}{c}\text { Öğrencilerin zengin } \\
\text { içerikler yardımıyla } \\
\text { ilgilerini artırma } \\
\text { avantajı }\end{array}$ & \\
\hline Ö3, Ö9, Ö12, Ö15 & $\begin{array}{l}\text { Öğrencinin bireysel } \\
\text { öğrenme hızına göre } \\
\text { öğrenme imkânı }\end{array}$ & \\
\hline Ö11 & $\begin{array}{c}\text { Öğretmenin } \\
\text { çizmekte } \\
\text { zorlandıkları } \\
\text { şekilleri görsel } \\
\text { materyal yardımıyla } \\
\text { sunabilme avantajı }\end{array}$ & \multirow{3}{*}{ 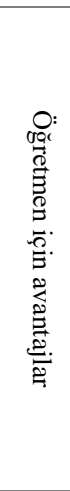 } \\
\hline Ö3, Ö12, Ö13, Ö16 & $\begin{array}{c}\text { Öğretmenlerin } \\
\text { dersleri daha kolay } \\
\text { kontrol edebilme } \\
\text { avantajı }\end{array}$ & \\
\hline Ö14 & $\begin{array}{c}\text { Öğretmenlerin } \\
\text { olumlu etkilerini } \\
\text { gördükleri içerikleri } \\
\text { birbirleriyle } \\
\text { paylaşma avantajı }\end{array}$ & \\
\hline $\begin{array}{l}\text { Ö6, Ö8, Ö10, Ö11, } \\
\text { Ö19 }\end{array}$ & $\begin{array}{l}\text { Zaman tasarrufu } \\
\text { sağlaması }\end{array}$ & \multirow{5}{*}{ 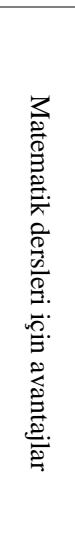 } \\
\hline Ö6, Ö9 & $\begin{array}{c}\text { Ekonomiklik } \\
\text { sağlaması }\end{array}$ & \\
\hline Ö1, Ö9, Ö10, Ö14 & $\begin{array}{c}\text { Farklı dokümanlar } \\
\text { sağlaması }\end{array}$ & \\
\hline Ö6, Ö7, Ö10, Ö12 & $\begin{array}{c}\text { Görsel materyaller } \\
\text { sağlaması }\end{array}$ & \\
\hline Ö2, Ö5 & $\begin{array}{l}\text { Yüz yüze eğitimin } \\
\text { verilemediği } \\
\text { durumlarda } \\
\text { verilmesi gereken } \\
\text { matematik } \\
\text { derslerinin web } \\
\text { tabanlı uzaktan } \\
\text { eğitim yoluyla } \\
\text { verilebilmesi }\end{array}$ & \\
\hline
\end{tabular}

Matematik öğretmenleri web tabanlı uzaktan eğitimin avantajları ile ilgili oldukça farklı bakış açıları sunmuşlardır. Özellikle tek bir konu üzerinde durulmamış hem öğretmen, 
hem öğrenci hem matematik dersleri için web tabanlı uzaktan eğitimin avantajlarına değinilmiştir. Kodlamada verilen ifadeler aslında dolaylı olarak bulunduğu tema dışında diğer temalar için de avantaj sağlamaktadır. Bu avantajlar birbirinden tamamen bağımsız değildir. Web üzerinden matematik derslerini tekrar izleme imkânı öğrencilerin dersleri tekrar edebilmesini sağlamıştır. Bu durumu Ö9 kodlu öğretmen “... ögrencide de ders kaydını istediği zaman izleyebilme imkânı doğdu” şeklinde ifade etmiştir. Ayrıca öğrenciler açısından ilgilerini artırması öğretmenlerin ifade ettikleri avantajlardan birisidir. Öğretmenler avantajları belirtirken en az öğrenci açısından ele almışlardır. Bunun sebebi web tabanlı uzaktan eğitimin en çok öğretmenlerde ve matematik derslerinde avantaj sağlayacağının düşünülmesi olabilir. Öğrencinin bireysel öğrenme hızına göre öğrenmesi imkânı öğretmenlerin dikkat çekici olarak sunduğu bir avantajdır. Örneğin Ö12 kodlu öğretmen "En önemli avantajı ögrencilerin kendi ögrenme hızına göre çalışabilme şansı oluyor. Yani her bir ögrenci aynı hızda ögrenemediği için özellikle matematik fen gibi derslerde çok daha yavaş olan ögrrenciler için kendi öğrenme hızına göre ders ayarlayabilme büyük bir avantaj oluyor" şeklindeki açıklaması kendisi için en büyük avantajın öğrencin öğrenmesini düzenlemeyi sağlama olduğunu göstermiştir. Matematik öğretmenlerinin öğretmenlere yönelik söyledikleri dezavantajlarda dikkat çekici konu öğretmenlerin dersleri daha kolay kontrol edebilmesi olmuştur. Ö12 kodlu öğretmen "Bence en büyük avantajlart öğrenci açısından öğretmen açısından da dersi kontrol edebilmek çok daha kolay hale geliyor. Çünkü dersin bütün unsurları ögretmen kendi elinde barındırıyor; dolayısıyla çok daha kolay olmuş oluyor ders süreci de. Öğretmen açısından avantaj da bu şekilde diye düşünüyorum" demiştir.

Öğretmenlerin en fazla avantaj sunduğu konu matematik dersleri için olmuştur. Matematik derslerindeki avantajlar beraberinde öğretmenleri ve öğrencileri etkilemektedir. Kaynak ve zaman tasarrufu konusu öğretmenler tarafindan önemli görülmüş̧ür. Ayrıca web tabanlı uzaktan eğitimin sağladığı farklı dokümanlar ve görsel materyaller matematik eğitimi için önemli avantajlardır. Ö12 kodlu öğretmen bu durumu şu şekilde açıklamıştır: "Matematikte birçok konuda özellikle geometride şekilleri veya üç boyutlu nesneleri katı cisimler gibi konularda ögrenciler canlandırma konusunda zihninde sorun yaşayabiliyor. Bunu daha teknolojik imkanlar sayesinde hani zengin işitsel ve görsel tasarımlar sayesinde ögrrencinin daha iyi canlandırmasını sağlayabiliyoruz. Bunlar bence en büyük avantajlarl”. Matematik derslerindeki avantajlar beraberinde öğretmenleri ve öğrencileri etkilemektedir görüşünün Ö12 kodlu öğretmenin yorumu ile desteklendiği de görülmüştür. Çünkü matematik eğitiminde sunulan zengin içerik öğrencilerin soyut kavramları öğrenmelerinde kolaylık sağlayacaktır. Ayrıca örgün eğitimin sağlanamadığ durumlarda web tabanlı uzaktan eğitim iyi bir alternatif olarak avantaj sağlamaktadır. Ö5 kodlu öğretmen "Web tabanlı uzaktan eğitim hem genel ĕgitim anlamında hem de matematik için gerekli, hiç eğitim olmamasındansa bilgileri taze tutmak gerekli ve önemli. Çocuklar da eminim ki internetle biraz daha haşır neşir oldular. Internetin sadece bu saçma Youtube videoları olmadığının farkına vardılar. Matematik üzerindeki avantajları sadece matematikten uzak kalmadan devam etmek" ve Ö2 kodlu öğretmen “Web tabanlı eğitim bu pandemi döneminde avantaja dönüştü” demiştir. Öğrencilere internetin faydası olabileceği de web tabanlı uzaktan eğitim ile gösterebilir hale gelmiştir.

Tablo 6. Matematik öğretmenlerinin web tabanlı uzaktan eğitimin matematik öğrenme-öğretme sürecindeki dezavantajlarına yönelik görüşleri

\begin{tabular}{|c|c|c|}
\hline Öğretmen & Kod & Tema \\
\hline Ö1, Ö7, Ö13 & $\begin{array}{l}\text { Öğrencilerin derse } \\
\text { katılım azlığ }\end{array}$ & \multirow{3}{*}{ 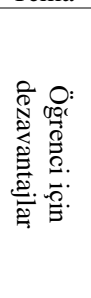 } \\
\hline Ö8 & $\begin{array}{c}\text { Öğrencinin dersi } \\
\text { dinleyemeyerek } \\
\text { ders sırasında oyun } \\
\text { oynaması }\end{array}$ & \\
\hline Ö15 & $\begin{array}{c}\text { Öğrencinin ders } \\
\text { çalışmak } \\
\text { istememesi }\end{array}$ & \\
\hline $\begin{array}{l}\text { Ö3, Ö5, Ö6, Ö9, } \\
\text { Ö12, Ö16, Ö17, } \\
\text { Ö18, Ö19 }\end{array}$ & $\begin{array}{c}\text { Öğrenciyle iletişim } \\
\text { kuramamak }\end{array}$ & \multirow{3}{*}{ 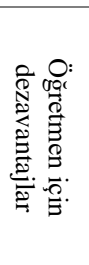 } \\
\hline $\begin{array}{c}\text { Ö1, Ö6, Ö7, Ö10, } \\
\text { Ö11 }\end{array}$ & $\begin{array}{l}\text { Öğrenciyi kontrol } \\
\text { edememek }\end{array}$ & \\
\hline Ö5 & $\begin{array}{c}\text { Öğretmenin } \\
\text { motivasyonunun } \\
\text { düşmesi }\end{array}$ & \\
\hline Ö1, Ö9 & $\begin{array}{c}\text { Matematik } \\
\text { derslerinde ölçme } \\
\text { değerlendirmenin } \\
\text { yapilamaması }\end{array}$ & \multirow{3}{*}{ 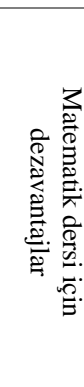 } \\
\hline Ö4 & $\begin{array}{l}\text { Web tabanlı uzaktan } \\
\text { eğitim ile aktif } \\
\text { öğrenmenin } \\
\text { yapılamaması }\end{array}$ & \\
\hline Ö2, Ö5, Ö19 & $\begin{array}{c}\text { Matematikteki } \\
\text { işlemleri } \\
\text { bilgisayarda yazma } \\
\text { sorunu }\end{array}$ & \\
\hline
\end{tabular}

Öğretmenlerin matematik öğrenme-öğretme sürecindeki web tabanlı uzaktan eğitimin dezavantajlarını değerlendirirken avantajları değerlendirirken olduğu gibi içinde bulundukları pandemi döneminin etkileri görülmüştür. Genel dezavantajlar teması web tabanlı uzaktan eğitim sistemi içerisinde yer alan her bir üye ve araç için geçerli olacak dezavantajları ifade etmek amaçlı kullanılmıştır. Öğrencilerin belirli sebeplerle derse katılım göstermemeleri web tabanlı uzaktan eğitim için bir dezavantaj oluşturmuştur. Öğrencilerin derse karşı ilgilerini kaybetmeleri yaşanan dezavantajlar arasındadır ve Ö8 kodlu öğretmen "Öğrencinin bu işin inceliklerini yeterince anlayamamasl, velinin bu konularda yetersiz kalıp takip edememesi durumunda; ders açı, arka planda oyun oynayan ögrenci yakaladık, tuşlara basıyor sesli böyle belli oluyordu. Ögrenci ders dinliyorum diyor, arka taraftan oyun oynayabiliyor" şeklindeki ifadesi ile deneyimden yola çıkarak bu duruma örnek göstermiştir. Matematik öğretmenleri en fazla öğretmenler için dezavantajlar temasına ilişkin görüş bildirmişlerdir. Öğrenciyle olan iletişimde sıkıntı yaşamak ve öğrencileri kontrol edememek öğretmenler için en sıkıntılı dezavantajlardır. Ö5 kodlu 
öğretmen yaşadığı sıkıntılı durumdan bahsederek öğrenciöğretmen iletişiminin önemini ortaya koymuştur: “... matematik zaten zor konsantre olunan ve ilgi çekilmesi gereken bir ders olduğu için göz göze temas olmayınca gerçekten çok zor oluyor. Yani ben tahtada genelde sesimi iyi kullanırım, gür sesim vardır. Genelde onunla dikkat çekmeye çalışıyorum. Ayrıca sınıf aralarında dolaşıyorsun ya da beklenmedik anlarda birine bir soru yöneltiyorsun. Bir kere göz göze kontak zaten eğitimin vazgeçilmezi. Bu konuda sıkıntı oldu. Yani tamam orada çocuk var ama bilgisayarda katılımcının ekranı açık ama gerçekten çocuk orada mı ya da ailesi için mi açıyor onu da bilemiyorsun. Dönüt almak istesen on kişi var diyelim mikrofonu açık olsa bu çocuk $2+$ 1 evlerde yaşlyorlar hepsinin 4, 5 kardeşi var sürekli bir ses var. O yüzden biz mikrofonlarl kapatıyorduk bütün ögretmenler olarak. Sadece ben anlattyorum dönüt alamıyorum". Öğretmenler için dersin verimini öğrencilerinden aldıkları dönütler göstermektedir. Ayrıca öğretmenler öğrencilerle olan etkileşim bozukluğu sebebiyle motivasyon kaybı yaşayabilmektedirler. Ö5 kodlu öğretmen “... benim için de motive düşüklüğ̈̈ oluyor ses tonum hep aynı gidiyor mesela. Çünkü o enerjiyi alamıyorsun ya sınıf enerjisi çok farklı bir şey. Ben monoton olabiliyorum" demiştir.

Matematik öğretmenlerinin dezavantaj konusundaki diğer görüşleri matematik dersi için olmuştur. Matematik derslerinde ölçme değerlendirme yapılamaması web tabanlı uzaktan eğitim için dezavantaj olmuştur. Ö9 kodlu öğretmen “... en çok hani ölçme değerlendirme de sıkıntı olduğunu düşünüyorum sinavı ögrencinin kendisinin yapıp yapmadı̆̆ından emin olamazsın" demiştir. Ayrıca aktif öğrenme yöntemlerinin uygulama kısmının web tabanlı uzaktan eğitim ile yapılamaması öğretmenler tarafindan ifade edilen bir diğer dezavantajlarındandır. Ö4 kodlu öğretmen "Aktif öğrenmeyi sağlayamaması, öğrencinin işin içine katılmasındaki zorluklar, somut öğrenmenin olamaması dezavantajlar" şeklinde ifade etmiştir ve bu ifade
Ö4 kodlu öğretmenin aktif öğrenme yöntemini önemsediğini göstermektedir. Genel dezavantajlar teması web tabanlı uzaktan eğitim sistemi içerisinde yer alan her bir üye ve araç için geçerli olacak dezavantajları ifade etmek amaçlı kullanılmıştır. Matematik dersleri uzun sayısal işlemlerin tahtaya yazıldığı bir derstir. Bu yazı işlemini web üzerinden yapmak teknolojik ekipmanı az olan öğretmenler için zordur. $\mathrm{Bu}$ durum hakkında Ö5 "Telefondan ya da bilgisayar faresinden matematik sorularını çözmek imkânsız. Bunun için grafik tablet olmallydl. Ki öyle zor sorular var ki sürekli çizmeniz gereken bir tahta boyunca süren yeni nesil sorular olabiliyor, bunu grafik tablette bile nereye kadar çözeceksin. Mesela fen eğitiminde iki üç açılklama yaparsın ekrana sı̆̆ar. Bu açılardan dezavantajı birincisi buydu. Matematik çok işlemsel olduğu için ekranda bunu yansitmak zor oluyordu" demiştir.

Dezavantajlar ve avantajlar birlikte ele alındığında öğretmenlerin farklı bakış açıları ile web tabanlı uzaktan eğitimi yorumladıkları görülmüştür. Öğretmenler avantaj ve dezavantajları ifade ederken öğrencilerin matematik öğrenmelerini daha etkili kılacak noktaları önemsemişlerdir. Öğrenci-öğretmen iletişimi bunlardan birisidir. Bu iletişimi sağlayabilen bir web tabanlı uzaktan eğitim sisteminin başarılı olabileceği düşünülmektedir. Buna ek olarak matematiği daha etkili öğretecek öğrenme ortamlarının web tabanlı uzaktan eğitim için hazırlanması önemlidir.

\subsection{Matematik Öğretmenlerin Web Tabanlı Uzaktan Eğitim Hakkındaki Önerileri}

Bu bölümde matematik öğretmenlerinin web tabanlı uzaktan eğitim konusunda matematik öğretim ve öğrenimi açısından değerlendirdiklerinde kaliteyi artırmak için önerilerinin neler olduğuna yer verilmiştir. Yapılan görüşmelerden elde edilen verilerin analizleri sonucu kod ve tema halinde Tablo 7'de verilmiştir. 
Tablo 7. Matematik öğretmenlerinin web tabanlı uzaktan eğitim konusunda matematik öğretim ve öğrenimi açısından değerlendirdiklerinde kaliteyi artırmak için önerileri

\begin{tabular}{|c|c|c|c|}
\hline Öğretmen & Kod & Alt Tema & Tema \\
\hline Ö2 & $\begin{array}{c}\text { Öğretmenler web tabanlı uzaktan eğitim derslerinden } \\
\text { önce hazırlı yapmalı }\end{array}$ & \multirow[t]{2}{*}{$\begin{array}{c}\text { Öğretmenin derse hazırlığı ile ilgili } \\
\text { öneriler }\end{array}$} & \multirow{6}{*}{$\begin{array}{l}\text { Öğretmene } \\
\text { Yönelik Önerileı }\end{array}$} \\
\hline Ö4 & Öğretmenler ders planları geliştirmeli & & \\
\hline Ö7 & $\begin{array}{c}\text { Öğretmenler kendilerini teknolojik açıldan geliştirip } \\
\text { yazılımlar öğrenmeli }\end{array}$ & \multirow{2}{*}{$\begin{array}{l}\text { Öğretmenin teknoloji kullanımı ile ilgili } \\
\text { öneriler }\end{array}$} & \\
\hline Ö12 & $\begin{array}{c}\text { Öğretmenler web tabanlı uzaktan eğitimi farklı } \\
\text { uygulamalar kullanarak desteklemeli }\end{array}$ & & \\
\hline Ö15, Ö18, Ö19 & $\begin{array}{c}\text { Öğretmen web tabanlı uzaktan eğitim sürecinde } \\
\text { öğrencilere rehberlik etmeli }\end{array}$ & \multirow{2}{*}{$\begin{array}{c}\text { Öğretmenin rehberlik rolüne yönelik } \\
\text { öneriler }\end{array}$} & \\
\hline Ö17 & $\begin{array}{c}\text { Öğretmen web tabanlı uzaktan eğitim sürecinde velilere } \\
\text { rehberlik etmeli }\end{array}$ & & \\
\hline Ö2, Ö11 & Bilgisayardaki yazı yazma problemi giderilmeli & & $\begin{array}{c}\text { Bilgisayar } \\
\text { Programcilarına } \\
\text { Yönelik Öneriler }\end{array}$ \\
\hline
\end{tabular}

\begin{tabular}{|c|c|c|c|}
\hline $\begin{array}{l}\text { Ö1, Ö5, Ö6, } \\
\text { Ö10, Ö17, Ö19 }\end{array}$ & Alt yapı sorunları giderilmeli & & \multirow{13}{*}{$\begin{array}{l}\text { Yöneticilere } \\
\text { Yönelik } \\
\text { Öneriler }\end{array}$} \\
\hline $\begin{array}{l}\text { Ö1, Ö5, Ö6, } \\
\text { Ö10, Ö16, Ö17, } \\
\text { Ö19 }\end{array}$ & Herkes için firsat eşitliği sağlanmalı & L & \\
\hline Ö3 & Türkçe dil desteği olan programların sayısı artırılmalı & \multirow{5}{*}{ Eğitim programlarına yönelik öneriler } & \\
\hline $\begin{array}{l}\text { Ö2, Ö4, Ö8, } \\
\text { Ö9, Ö14 }\end{array}$ & Farklı teknolojik araçlar veya programlar geliştirilmeli & & \\
\hline Ö4 & EBA daha kolaylaştırılmalı & & \\
\hline Ö5 & EBA not sistemine bağlanmalı & & \\
\hline Ö13 & EBA zenginleştirilmeli & & \\
\hline Ö3 & $\begin{array}{c}\text { Dijital öğretim araçları ile ilgili öğretmenlere eğitim } \\
\text { verilmeli }\end{array}$ & \multirow{2}{*}{$\begin{array}{l}\text { Öğretmen eğitimine Yönelik } \\
\text { Öneriler }\end{array}$} & \\
\hline Ö14 & $\begin{array}{c}\text { Var olan matematiksel programlar ile ilgili öğretmenler } \\
\text { uzmanlaştırılmalı }\end{array}$ & & \\
\hline Ö10 & Kazanım kavrama testleri güncellenmeli & \multirow{4}{*}{$\begin{array}{l}\text { İçeriğe } \\
\text { Yönelik } \\
\text { Öneriler }\end{array}$} & \\
\hline Ö10, Ö19 & İçerik sıkıntısı giderilmeli & & \\
\hline Ö14 & İçeriklerin güvenli olmasına dikkat edilmeli & & \\
\hline Ö16 & $\begin{array}{c}\text { Ders içerikleri ile ilgili dokümanlar öğrencilere } \\
\text { ulaștırılmalı }\end{array}$ & & \\
\hline Ö8, Ö14, Ö18 & $\begin{array}{c}\text { Üniversitede web tabanlı uzaktan eğitim ile ilgili dersler } \\
\text { hazırlanmalı }\end{array}$ & \multirow{2}{*}{$\begin{array}{l}\text { Akademisyenlerin eğitimdeki rolüne } \\
\text { yönelik öneriler }\end{array}$} & \multirow{2}{*}{$\begin{array}{l}\text { Akademisyenlere } \\
\text { Yönelik Öneriler }\end{array}$} \\
\hline Ö7, Ö15, Ö18, & Akademisyenler ögrretmenlere eğitim vermeli & & \\
\hline
\end{tabular}

Matematik öğretmenlerinin web tabanlı uzaktan eğitimi daha kaliteli hale getirmek amaciyla ifade ettikleri öneriler incelendiğinde birbirinden farklı bakış açılarının ortada olduğu görülmektedir. Öğretmenlere yönelik öneriler teması altında öğretmenlerin uyması gereken tavsiyeler toplanmıştır. Öğretmenlere yönelik tavsiyelerde hem öğretmenin dersi daha verimli işlemek adına yapacağı adımlar hem de öğretmenin teknolojik kimliği kazanacağı işler yer almaktadır. Örneğin Ö4 kodlu öğretmen "Bir kere bunun için ders planları geliştirilebilmesi lazım. Yani bunun bir öğretim yöntemi, öğretim modeli olarak ele alınması gerekiyor. Ders planlarl geliştirilmediği sürece yani eski sistem gibi sene başından veya belirli bir dönem öncesinde zümrelerle beraber bu iş yapılmadiğg sürece çok da să̆lıklı yürüyeceğini düşünmüyorum” şeklindeki açıklaması ile zümre toplantılarında web tabanlı uzaktan eğitim süreci için öğretmenlerin planlama yapılabileceğini ortaya koymuştur. Ayrıca Ö7 kodlu öğretmen "Ögretmenler kendilerini geliştirmeli, farkl yazllımlar daha aktif olarak kullanılabilir" şeklindeki ifade ile öğretmenlerin teknolojik bir kimlik kazanmaları gerektiğini savunmuştur. Teknolojik kimlik kazanan öğretmenler web tabanlı uzaktan eğitim sürecinde matematik derslerini daha anlamlı kılabilecek uygulama ve programlara yer verebileceklerdir. Öğretmenler için sadece dersleri verimli kılmak değil öğrencilerin psikolojik durumları da oldukça önemlidir. Öğrencilere okul dışında ya da okul içinde destek sunmanın öğrencilerin gelişimine olumlu etki edeceği düşünülmektedir. Ö18 kodlu öğretmen “Öğretmenler bu süreçte ögrrencilere psikolojik olarak da destek vermeli sadece akademik başarlya odaklanmamall" demiştir.

Bilgisayar programcılarına yönelik öneriler temasına ilişkin görüş öğretmenlerin yaşadığ 1 bir problemin çözümünü gerçekleştirebilmek için sunulan öneridir. Matematik sayısal bir derstir. Dolayısıyla içeriğinde yer alan işlemleri göstermek diğer derslere kıyasla sıkıntılı olabilmektedir. Ö11 kodlu öğretmen "Kaliteyi arttırmak için belki bu yazma konusunda kalem uygulamaları oluyor daha kolay yazması için, onlar geliştirilebilir" demiştir. Yazı yazma araçlarının geliştirilmesinin öğretmenlerin ders anlatımında kolaylık sağlayacağı düşünülmektedir.

Yöneticilere yönelik öneriler temasına ilişkin veriler birbirinden oldukça farklılaşmaktadır. Yöneticiler, Türkiye'de eğitim-öğretim faaliyetlerinden sorumlu kişilerdir. Özellikle alt yapı problemi ve firsat eşitliği konusu 
öğretmenlerin çoğunun görüşlerinin yer aldığı ortak payda olmuştur. Bu konulara diğer konulara kıyasla daha fazla değinilmesinin sebebi web tabanlı uzaktan eğitim sisteminin temelinin internet alt yapısı ile doğrudan ilişkili olması ve sağladığı en büyük avantajın firsat eşitliği olması olabilir. Ö5 kodlu öğretmen "Birincisi kesinlikle daha iyi bir alt yapı lazım. Ki bizim internetimiz bile sorunlu. Ufak bir felakette hatlarımız kilitleniyor. EBA'da milyonlarca öğrenci giriş yaplyor. Ilk hafta kimse giremiyor internete. Sonra okullar saatlere böldüler. Mesela bizim okul saat 9 ile 11 arast girebiliyor. İdarecilerimiz ona göre ders programı yapıyorlardı yı̆̆llmayı önlemek adına. Böyle yaptılar ona rağmen bile bir sürü hata oluştu. Bir kere altyapı çok önemli altyapı iyileştirilmeli" şeklindeki açıklaması ile kendi deneyiminden yola çıkarak önceliği alt yapı sorunlarının giderilmesini önermiştir. Ö1 kodlu öğretmen ise "Benim Muş'taki öğrencimin ve İstanbul'daki herhangi bir semtteki öğrencinin eşit olanaklarının olması gerekiyor, eğitimde firsat eşitliğini sağlamamı gerekiyor", diyerek Türkiye'nin her bir ilindeki öğrencinin aynı imkana sahip olması gerektiğini savunmuştur.

Matematiksel programlara yönelik öneriler temasına ilişkin bulgular, matematik öğretmenlerinin web tabanlı uzaktan eğitim sisteminde yararlanacakları programları daha verimli kılacak önerileri içermektedir. Farklı teknolojik araçların ve programların geliştirilmesi web tabanlı uzaktan eğitim sürecinde daha fazla kaynak ve içerik sağlayacaktır. Ö14 kodlu öğretmen "Web tabanlı olduğu için dijital ortamdaki matematiksel bazl programlar tasarlanabilir. Yani daha güzel, bizim her ders için konularl öğrencilere sunabileceğimiz. Görselleştirilebilir, zenginleştirilebilir yani daha somut hale getirmek için” şeklindeki önerisi ile matematiksel programların aslında dersleri zenginleştirmek ve anlamlı öğrenmeyi sağlamak adına önemli olduğunu ortaya koymuştur. Öğretmenlerin son zamanlarda en fazla deneyim kazandıkları web ortamı EBA olmuştur. Dolayısıyla EBA'ya yönelik öneriler de öğretmenler tarafindan sunulmuştur. Örneğin Ö4 kodlu öğretmen “Biz bir platform üzerinde yayın yapıyoruz (EBA). Platformdan öğrenciye her şeyi yansitmak kolay olmuyor, bunlar için daha da kolaylaştırabilecek şeyler oluşturulursa katkısı olur diye düşünüyorum" demiştir. Benzer şekilde Ö13 kodlu öğretmen ise "EBA'ya daha farklı içerikler konulabilir" demiştir.

Öğretmen eğitimi konusu da matematik öğretmenlerinin web tabanlı uzaktan eğitimi daha kaliteli hale getirebilmek için öneriler sunduğu bir başka konu olmuştur. Burada öğretmenlerin web tabanı üzerinden ders yapmaları ile ilgili olarak eğitimlerin verilmesi gerektiği düşünülmüştür. Örneğin Ö14 kodlu öğretmen "Skectpad, Geogebra gibi bazı uygulamalar var. Bunlarla ilgili milli ĕgitim bizleri daha uzmanlaştırırsa bence daha faydalı olacağımızı düşünüyorum ben. Bazı uygulamalar bazı şeyleri çok daha kolaylaştırabilir" demiştir. Yani mevcut programlarla ya da araçlarla öğretmenlerin web tabanlı uzaktan eğitim sürecinde daha verimli olması sağlanmalıdır. Veliler de eğitim sisteminin vazgeçilmez bir parçasıdır. Web tabanlı uzaktan eğitim süreci ile ilgili bilgilendirilmiş velilerin, öğrencilerin bu süreci daha iyi geçirmelerini sağlayacakları düşünülmektedir. Ö17 kodlu öğretmen "Çocukların sorumsuzluğunun önüne geçmek için velilerle konuşulabilir, veliler bu süreçle ilgili bilgilendirilebilir. Çünkü veliler de bilmiyor ne yapacaklarını. Çocuk bana mesaj atıyor hocam bana ödev verin diyor ama ben bilmiyorum o hangi seviyede. Bu konuda velilere çok büyük iş düşüyor onlar daha iyi bir şekilde bilinçlendirilebilir" demiştir. $\mathrm{Bu}$ açıklama ile öğretmenden uzak kalan küçük yaştaki öğrenciler için velilerin desteğinin önemli olduğu görülmüştür. İçeriğe yönelik önerilerde matematiksel ders içeriklerinin öğrencilere iletilmesi ve içeriğin iyileştirilmesi önemli görülmüştür. Ö16 kodlu öğretmen “... dokümanın önlerinde olması lazım sadece bilgisayar ortamında değil. Çünkü çocuk gerektiği zaman kendisi de yazacak çizecek. Matematik denemesi 40 dakikadır. Biz internette yaptığımız zaman 45-50 dakika yapıyoruz. Çünkü ekrandakini kâğıda geçiriyor, kağıttakini de çözmeye çalışlyor. Bunu yapmak yerine ĕger bu sistemli bir şekilde yapılacaksa dokümanlar önceden hazır edilip çocukların ellerine A4 kağıdında verilmeli. Onun haricinde çok zor oluyor" demiştir. Ö16 kodlu öğretmen web tabanlı uzaktan eğitim deneyiminden yola çıkarak sunduğu bu öneri ile öğrencilerin ders esnasında yaşadıkları sıkıntıların önüne geçmeyi hedeflemiştir. Eğitim fakültesindeki akademisyenler geleceğin öğretmenlerinin mimarlarıdırlar. Aynı zamanda eğitim alanında yapılan çalışmaların öncüsüdürler. Dolayısıyla daha iyi bir web tabanlı uzaktan eğitim için akademisyenlere de rol düşmektedir. Ö15 kodlu öğretmen bu konuda “Öğretmenlere akademisyenler tarafindan seminerler verilebilir. Öğretmenler de bunları ögrencilere aktarır" demiştir. Buna benzer şekilde Ö18 kodlu öğretmen "Üniversitelerde kendi alanında bilgisayar kullanımına ilişkin dersler verilmeli bu dersler zorunlu olmalı" diyerek web tabanlı uzaktan eğitim sisteminin öğretmen eğitiminde yer alması gerektiğini belirtmiştir.

Elde edilen tüm veriler matematik öğretmenlerinin farklı bakış açılarına sahip olduğunu ve web tabanlı uzaktan eğitim konusunda yaşanan olumlu ve olumsuz durumları ortaya koymuştur. Öğretmenlerin görüşleri doğrultusunda matematik eğitiminde web tabanlı uzaktan eğitim sürecini daha etkili kılacak çalışmalara yer vermenin önemli olduğu düşünülmektedir. Öğrencilerin derslere katılım gösterebileceği, öğretmenlerin teknolojik kimlik kazandığı ve kaliteli içeriklerle dolu dijital ortamların geliştirildiği çalışmalar bunlara örnektir.

\section{Tartışma, Sonuç ve Öneriler}

$\mathrm{Bu}$ çalışmada ortaokul matematik öğretmenlerinin matematik derslerinde web tabanlı uzaktan eğitim ile ilgili algıları incelenmiş ve web tabanlı uzaktan eğitim konusundaki önerileri alınmıştır. Matematik öğretmenlerinin web tabanlı uzaktan eğitim ile ilgili genel düşünceleri birbirinden oldukça farklı bakış açılarını yansıtmaktadır. Öğretmenlerin birbirlerinden farklı düşünceler sunmalarındaki sebebinin Türkiye'nin farklı bölgelerinde ve farklı yaş aralığında olmaları olduğu düşünülmektedir. 
Öğretmenlerin çoğunluğu web tabanlı uzaktan eğitimi faydalı olarak nitelendirmişlerdir. Yorgancı (2014) da web tabanlı uzaktan eğitimin öğrencilerin başarısını artırmada etkili bir yöntem olabileceğini öne sürmüştür. Yazlık ve Erdoğan (2019) ise web tabanlı uzaktan eğitimin öğrencilerin matematiksel kavramları anlamalarını kolaylaştırdığını ve akademik başarılarını artırdığını söylemiştir. Öğretmenler son dönemin etkisi ile en çok EBA ve Zoom platformu üzerinde deneyim yaşamışlardır. EBA, MEB tarafından desteklenen web tabanlı öğrenme ortamıdır. Ayrıca internet alt yapısından kaynaklı sorunlar ve öğrencilerin derslere katılım göstermemeleri öğretmenlerin en çok zorluk yaşadığı durumlar olmuştur.

Öğretmenler web tabanlı uzaktan eğitimin matematik eğitiminin her bir parçası üzerindeki etkisini ele almışlardır. Burada en çok dikkat çeken konu öğretmenlerin çoğunluğunun web tabanlı uzaktan eğitimin matematik üzerinde etkili ve verimli olmadığını düşünmesi olmuştur. Bunun sebebi matematiğin daha çok fiziksel sınıf ortamında gerçekleşmesi gerektiğini düşünmeleridir. Fedele ve Li (2008) de matematik dersleri için web tabanlı uzaktan eğitimin kendi başına yetersiz olduğunu vurgulamışlardır. Ayrica, Amin ve Li (2010) matematik derslerinde öğrencilerin arasındaki bağ ve desteğin, bazı öğrencilerin zor engellerin üstesinden gelmelerinde önemli bir faktör olduğunu ifade etmişlerdir. Özellikle başarı durumu daha düşük öğrenciler için bu durum geçerlidir. Yani fiziksel bir sınıf ortamı etkili matematik öğretimin kaçınılmaz bir parçası olarak görülmektedir. Buna karşın Arslan’ın (2008) web destekli öğretimin ve materyal kullanımının ilköğretim öğrencilerinin matematik kaygılarına, tutumlarına ve başarılarına etkisini incelediği çalışmada öğrencilerin matematik başarısına ve matematik kaygısına anlamlı düzeyde etki ettiği sonucuna ulaşmıştır. Benzer şekilde Yorgancı (2013) da çalışmasında web tabanlı öğretimin öğrencilerin matematik başarısına önemli düzeyde etki ettiğini söylemiştir.

Matematik öğretmenlerinin belirttiği web tabanlı uzaktan eğitimde öğrenci için avantaj olan durumların aslında öğretmen ve matematik öğretimi açısından da avantaj sağladığı görülmüştür. Mupinga (2005) web tabanlı uzaktan eğitimin faydaları arasında öğrenciler için zaman ve mekân esnekliği sağlaması olduğunu belirtmiştir. $\mathrm{Bu}$ esneklik bir avantajdır. Öğretmenler de benzer şekilde web tabanlı uzaktan eğitimin öğrenciler için birçok görsel ve işitsel materyaller sunarak ekonomiklik ve zaman tasarrufu sağladığını dile getirmişlerdir. Web tabanlı eğitimde içeriğin metin, video ve ses formatlarında sunulmasını mümkün kılarak katılımcıların ilgisini çekebileceğini ve karmaşık bilgileri anlamaya yardımcı olabileceğini belirten birçok çalışma mevcuttur (Burmark, 2004; Kenny 2002; Lu ve diğerleri, 2009). Greenhalgh (2001) ise web tabanlı eğitimin öğrenenin bağımsızlığını ve kendi kendini yönetmesini sağladığını belirterek bireyselleştirme konusundaki avantajı vurgulamıştır. Ünsal (2012) yaptığı çalışmada web tabanlı öğrenmede bilgiye erişim, esneklik, tekrarlanabilirlik, izlenebilirlik, bireysel farklılıklara uygunluk, farklı öğrenme biçimlerine görelik, öğrenme etkinliklerinin çokluğu, kendi hızında ilerleme, maliyetin azlığı gibi avantajlar belirtmiştir. Bu çalışmada ise öğretmenler Ünsal'ın (2012) çalışmasında olduğu gibi tekrarlanabilirlik, bireysel farklılıklara uygunluk, öğrenme etkinliklerinin çokluğu, kendi hızında ilerleme ve maliyetin azlığı kavramları ile web tabanlı eğitimin avantajlarını dile getirmişlerdir.

Matematik öğretmenlerinin web tabanlı uzaktan eğitimin matematik öğrenme-öğretme sürecindeki dezavantajlarına yönelik olarak en fazla öğrencilerle iletişim kuramamak ve öğrencileri kontrol edememek görüşlerini vurgulamışlardır. Koçer (2001) de uzaktan eğitimin en belirgin dezavantajının eğitimcilerin öğrencilerin tepkilerini, derse katılımını ve konuyu anlayıp anlamadığını bilememeleri olduğunu söylemiştir. Öğrenciler, web tabanlı eğitimde kendilerini izole hissetmektedirler (Adams ve Timmins, 2006). Matematik öğretmenlerinin etkili bir iletişim kurmaları öğrencilerin matematik başarısında etkili rol oynamaktadır (Hadfield,1992). Mavrikis ve Maciocia (2003) yaptığ çalışmada web tabanlı grubun daha yüksek başarıya ulaşmasının bir açıklaması olarak ödevler üzerinde anında ve uyarlanmış geri bildirim alınması olduğunu ifade etmişlerdir. Ödevlerde anında dönüt vermek; öğrencinin hatalarını fark etmelerinde ve tekrarlayarak doğru çözümlere ulaşmalarında yardımcı olmuştur. Öğretmen-öğrenci iletişimi matematik eğitimi açısından önemlidir. $\mathrm{Bu}$ çalışmada web tabanlı eğitim üzerinden öğrencilerle iletişimde sorun yaşayan öğretmenler öğrencileri kontrol edememek ve dönüt sağlayamamak konusundaki olumsuz deneyimlerini aktarmış ve bu durumu dezavantaj olarak değerlendirmişlerdir. Bunun sebebinin Türkiye'nin web tabanlı uzaktan eğitim sistemine yabancı kalması olduğu düşünülmektedir. Web tabanlı uzaktan eğitim sistemine tam olarak adapte olunmadığı için öğrencileri kontrol edebilecek ve uygulamalı ödevler verebilecek bir platform Türkiye'de tam olarak kullanılmamıştır.

Öğretmenler tarafından web tabanlı uzaktan eğitim sistemi içerisinde yer alan öğretmenlere, velilere, yöneticilere ve alanında uzman akademisyenlere öneriler sunulmuştur. Öğretmenlerin sunduğu öneriler web tabanlı uzaktan eğitim sistemini daha kaliteli hale getirecek dikkate değer önerilerdir. Örneğin öğretmenlerin web tabanlı uzaktan eğitim hakkında kendilerini geliştirmeleri ve bilgisayar programcıları tarafından matematik derslerinde öğrencilere sunulacak zengin görsel ve işitsel materyallerin hazırlanması tavsiye edilmiştir. Adams ve Timmins (2006) de web tabanlı derslerin bir gerekliliğinin bilgisayar teknolojileri becerisine sahip olmak olduğunu belirtmiş ve bu konuda çözüm sağlayacağını düşündüğü programlar için teknik destek bir çalışma yapılmasını önermiştir. Bunlara ek olarak öğretmenler firsat eşitliği ve alt yapı sorunları ile ilgili de öneriler sunmuşlardır. $\mathrm{Bu}$ öneriler 1şı̆̆ında iyileştirici çalışmalar yapılmalıdır. Öğretmenler öğrenciler için herhangi bir öneri dile getirilmemiştir. Bunun sebebi, öğrencilerden beklenen olumlu davranışların sistemdeki diğer öğelerin iyileştirilmesinden sonra gelebileceğinin düşünülmesi olabilir. Fırsat eşitliği sağlama ve alt yap1 sorunları öğretmenlerin önerilerini dile getirirken oldukça üzerinde durdukları konular olmuştur. Web tabanlı uzaktan 
eğitiminin temelinde fırsat eşitliği konusu vardır. Fırsat eşitliği, eğitimsel kaynaklara ulaşabilme ve onlardan yararlanma konusunda eşitliğin sağlanmasını ifade etmektedir (Yeşil, 2003). Web tabanlı uzaktan eğitimin sistematik bir şekilde yürütülmesi için Türkiye'deki her bir öğrencinin internete erişebilmesi gerekmektedir. Bu sebeple Türkiye'nin farklı bölgelerinde bulunan öğretmenlerin bu konuda fikir birliği içerisinde olmaları beklenen bir durumdur. Öğretmenlerin sundukları öneriler öğretmenlik yaptıkları illere göre değişmemiştir. Öğretmenler önerileri ifade ederken Türkiye geneli öğrencilerin web tabanlı uzaktan eğitim sistemi içerisinde kaliteli eğitim almalarını dikkate almışlardır.

Turgut ve Yenilmez (2011) matematik eğitimi lisansüstü öğrencilerinin web tabanlı eğitime ilişkin görüşlerini incelediği çalışmada en dikkat çekici sonucun lisansüstü öğrencilerin web tabanlı matematik eğitimini bir sınıf içi etkinlik olarak algılamaları olduğunu belirtmiştir. $\mathrm{Bu}$ çalışmada ise matematik öğretmenleri web tabanlı matematik eğitimini bir uzaktan eğitim sistemi olarak değerlendirmişlerdir. Çünkü pandemi döneminde yaşanan sıkıntılar sebebiyle Türkiye'de zorunlu olarak uzaktan eğitim sistemine geçilmiştir. Dolayısıyla web tabanlı eğitimi deneyimleyen öğretmenler fikirlerini sunarken web tabanlı eğitimi bir eğitim sistemi olarak ele almışlardır. Sonuç olarak bu çalışmada öğretmenlerin web tabanlı uzaktan eğitim ile ilgili algıları ortaya konmuştur. Matematik öğretmenlerinin web tabanlı uzaktan eğitim ile ilgili yaşadıkları deneyimlerin etkisi ile dile getirdikleri düşünceler 1şığında web tabanlı uzaktan eğitimin etkili bir yöntem olduğu fakat uygulama kısmında zorluklarla karşılaşıldığı görülmüşsür.

Öğretmenlere, öğrencilere ve velilere eğitim-öğretim için uygun dijital platformların tanıtılacağı ve nasıl kullanılacağının açıklanacağı videoların oluşturulması ve ilgili sistemler üzerinden paylaşılması önerilmektedir. Matematik öğretmenlerinin web tabanlı uzaktan eğitim içerisinde daha etkili matematik öğretimi sağlamak amacıyla mesleki açıdan kendilerini geliştirme ve web tabanlı uzaktan eğitimin teknolojik araçlarını kullanmayı üst düzeyde öğrenme gerekliliği oluşmaktadır. $\mathrm{Bu}$ bilgilerin uzman kişiler tarafından paylaşacağı uzaktan eğitim seminerlerinin düzenlenmesi önerilmektedir. Ayrıca, eğitim fakültelerinde programlara web tabanlı uzaktan eğitim konusunda ders eklenebilir ya da programların mevcut derslerine etkili web tabanlı uzaktan eğitime ilişkin içerikler konulabilir. Ülkemizin eğitim sistemi içerisinde yer alan yöneticiler açısından ise fırsat eşitliği ve alt yapı konularında iyileştirici çalışmalar yapma gerekliliği ortaya çıkmaktadır. Araştırmacıların son dönemin kaçınılmaz eğitim sistemi olan web tabanlı uzaktan eğitim sistemi konusunda daha fazla çalışma yapmasına ihtiyaç duyulmaktadır. Öğretmenlerin yanı sıra öğrencilerin web tabanlı uzaktan eğitim deneyimlerinden yola çıkarak ortaya koyacakları görüşlerin toplandığı nitel çalışmaların son dönemde yaşanan eğitim problemlerinin çözülmesinde olumlu etki göstereceği düşünülmektedir. Dolayısıyla eğitimin her kademesinde yer alan öğrencilerin web tabanlı uzaktan eğitime ilişkin görüşlerinin incelendiği çalışmaların yapılması önerilmektedir. Bu çalışma kapsamında web tabanlı uzaktan eğitime ilişkin öğretmenlerle nitel bir çalışma yürütülmüştür. Literatürü web tabanlı uzaktan eğitim konusunda zenginleştirmek adına web tabanlı uzaktan eğitim konusunda ögrencilerin ve velilerin de dahil olduğu daha fazla sayıda ve farklı katılımc1 gruplarla uzun periyotlu ve nitel desenin yanı sıra nicel çalışmaların yapılması önerilmektedir. Web tabanlı uzaktan eğitimin zaman geçtikçe değer kazandığı görülmektedir. Dolasıyla araştırmacılar web tabanlı uzaktan eğitim sistemi içerisinde uygulanacak eğitim faaliyetlerinin daha etkili öğretim sağlaması için deneysel çalışmalar yürütülebilir. Deneysel çalışmalarda web tabanlı uzaktan eğitim sisteminde uygulanabilecek öğretim yöntem ve tekniklerin etkisi üzerinde durulması faydalı olabilir.

\section{Kaynakça}

Adams, A., \& Timmins, F. (2006). Students views of integrating web-based learning technology into the nursing curriculum-adescriptive survey. Nurse Education in Practice, 6(1), 12-21.

Amin, R. \& Li, K. (2010). Should graduate mathematics courses be taught fully online? The Electronic Journal of Mathematics \& Technology, 4(1), 47-56.

Arslan, A. (2008). Web destekli ögretimin ve ögretimsel materyal kullanımının ilköğretim öğrencilerinin matematik kaygılarına, tutumlarına ve başarılarına etkisi. (Doktora Tezi). Marmara Üniversitesi, İstanbul.

Bayram, Y. \& Aksoy, M. (2002). Türkiye'de uzaktan eğitim ve Sakarya üniversitesi uygulaması. Sakarya University Journal of Science, 6(1), 169-175.

Bulurman, B. (2002). On-Line eğitim. Endüstri İlişkileri ve Insan Kaynakları Dergisi, 4(2).

Burmark, L. (2004). Visual presentations that prompt, flash \& transform. Media and Methods, 40(6), 4-5.

Creswell, J. W. (2020). Nitel araştırma yöntemleri: Beş yaklaşıma göre nitel araştırma ve araştırma deseni. Ankara: Siyasal Kitabevi.

Çağıltay, K. (2001). Uzaktan eğitim: Başarıya giden yol teknolojide mi yoksa pedagojide mi? 5 May1s 2020 tarihinde

http://www.teknoturk.org/docking/yazilar/tt000037y azi.htm adresinden erişildi.

Fedele, F. \& Li, K. (2008). Reasoning and problem solving: an assessment on two general education courses, Technical Report, The University of West Florida.

Girginer, N. 2001. Uzaktan eğitim kararlarında teknoloji, maliyet, etkinlik boyutları ve uzaktan eğitime geçiş için kavramsal bir model önerisi. (Doktora tezi). Anadolu Üniversitesi Sosyal Bilimler Enstitüsü, Eskişehir. 
Greenhalgh, T. (2001) Computer assisted learning in undergraduate medical education. British Medical Journal, 322(7277), 40-44.

Hadfield, J. (1992). Classroom dynamics. Oxford: Oxford University Press.

Kaya, Z. (2006). Öğretim teknolojileri ve materyal geliştirme. Ankara: Pegem A Yayıncılık.

Kenny, A. (2002) Online learning: Enhancing nurse education? Journal of Advanced Nursing, 38(2), 127135.

Koçer, H. E. (2001). Web tabanlı uzaktan eğitim. (Yüksek Lisans Tezi). Selçuk Üniversitesi Fen Bilimleri Enstitüsü, Konya.

Lin, C. (2009). A comparison study of web-based and traditional instruction on preservice teachers' knowledge of fractions. Contemporary Issues in Technology and Teacher Education, 9(3), 257-279.

Lu, D.F., Lin, Z.C. \& Li, Y.J. (2009) Effects of a Web-based course on nursing skills and knowledge learning. The Journal of Nursing Education, 48(2), 70-77.

Mavrikis, M., \& Maciocia, A. (2003). Incorporating assessment into an interactive learning environment for mathematics. Maths CAA Series, 1-17. 5 Haziran 2020 tarihinde http://icse.xyz/mathstore/repository/mathscaa_jun20 03.pdf adresinden erişildi.

Mupinga, D. M. (2005). Distance education in high schools: Benefits, challenges, and suggestions. The Clearing House: A Journal of Educational Strategies, Issues and Ideas, 78(3), 105-109.

Nguyen, D. M., \& Kulm, G. (2005). Using web-based practice to enhance mathematics learning and achievement. Journal of interactive online learning, 3(3), 1-16.

Odabaş, H. (2003). Internet tabanlı uzaktan eğitim ve bilgi ve belge yönetimi. Türk Kütüphaneciliği, 17(1), 2236.

Orhan, A. T., \& Men, D. D. (2018). Web tabanlı öğretimin fen dersi başarısına ve fen dersine yönelik tutumuna etkisi: Bir meta analiz çalışması. Celal Bayar Üniversitesi Sosyal Bilimler Dergisi, 16(3), 245-284.

Özdil, İ. (1986). Uzaktan ögrretimin evrensel çerçevesi ve türk ĕgitim sisteminde uzaktan ögretimin yeri. Eskişehir: T.C. Anadolu Üniversitesi Açık Öğretim Fakültesi Yayını.
Özüsağlam, E. (2007). Web tabanlı matematik öğretimi ve ders sunum örneği. Pamukkale Üniversitesi Eğitim Fakültesi Dergisi, 21(21), 33-43.

Summerlin, J. A. (2003). A comparison of the effectiveness of off-line internet and traditional classroom remediation of mathematical skills. (Unpublished doctoral dissertation). Baylor University, Texas.

Şen, B., Atasoy, F. \& Aydın, N. (2010). Düşük maliyetli web tabanlı uzaktan eğitim sistemi uygulaması. XII. Akademik Bilişim Konferansı, Sitkı Koçman Üniversitesi, Muğla.

Toptaş, E. (2001). Uzaktan eğitim ve kütüphanecilik bölümlerinde uygulanmasl: A.̈̈. dil ve tarihcoğrafya fakültesi kütüphanecilik bölümü için bir model. (Yüksek Lisans Tezi). Ankara Üniversitesi, Ankara.

Turgut, M., \& Yenilmez, K. (2011). İlköğretimde web tabanlı matematik eğitimine ilişkin lisansüstü öğrencilerin görüşleri. Turkish Journal of Computer and Mathematics Education, 2(2), 121-139.

Ünal, B. B. (2017). Web tabanlı uzaktan eğitimin fen bilimleri konularında öğrenci başarısına etkisi. Uluslararası Türk Eğitim Bilimleri Dergisi, 5(9), 481-490.

Ünsal, H. (2012). Harmanlanmış öğrenmenin başarı ve motivasyona etkisi. Türk Eğitim Bilimleri Dergisi, 10(1), 1-27.

Van Manen, M. (1990). Researching lived experience. New York: State University of New York Press.

Yalçınkaya, S. (2006). Web tabanlı uzaktan ĕgitim sistemi ve Çukurova Üniversitesi öğretim elemanlarının yatkınlıklarl. (Yüksek lisans tezi). Çukurova Üniversitesi, Adana.

Yazlık, D.Ö, Erdoğan, A. (2019). The effect of individualized web based mathematics learning environment developed based on problem solving steps on the students' academic achievements. Atatürk Üniversitesi Sosyal Bilimler Enstitüsü Dergisi, 23(4), 1693-1706.

Yeşil, R. (2003). Demokratik eğitim ortamının insan hakları temeli, G.Ü. Kırşehir Eğitim Fakültesi Dergisi, 4(2), 45-54.

Yorganc1, S. (2013). Web tabanlı uzaktan eğitim yönteminin öğrencilerin matematik başarılarına etkileri. Kastamonu Ĕgitim Dergisi, 23(3), 1401-1420. 


\section{Extended Abstract}

Unlike traditional education, distance education is called education conducted by using specially prepared written materials, mass communication programs and short-term face-to-face teaching within a system that does not depend on the place, method, purpose, time, teaching age and similar limits (Girginer, 2001). One of the first universities to offer distance education in an organized structure is Pennsylvania State University, which established the first distance learning network in 1886. Distance education studies in our country date back to the 1920 s.

Web-based education is a form of education that supports distance education, is prepared via the web, offers access opportunities regardless of time and place, and requires connecting to a network in order to reach it (Kaya, 2006). Web-based distance education is an alternative that can be used especially in situations where formal education cannot be provided (illness, natural disaster, war, etc.). Recently, the concept of web-based distance education has gained importance with the widespread use of technology. The aim of this study was to determine the views of mathematics teachers about web-based distance education in mathematics lessons. For this purpose, the following questions were sought:

1. What are the opinions of mathematics teachers towards webbased distance education in mathematics education?

2. What are the suggestions of mathematics teachers about webbased distance education?

The design of this study is phenomenology, one of the qualitative research methods. Phenomenological study explores the common perceptions of more than one person's experiences of a phenomenon (Creswell, 2020). The concept of "web-based distance education" constitutes the phenomenon in this study. The study group consists of 19 people teaching middle school mathematics in different provinces. Maximum diversity sampling was used in this study. The aim is to increase the likelihood of reflecting different perspectives (Creswell, 2020). In this study, a semi-structured interview form with 8 open-ended questions was used to get the opinions of mathematics teachers about web-based distance education. The interviews took place through the phone with the teachers and lasted approximately 20-30 minutes. All of the speeches were recorded with a recording device with the permission of the participants. Interviews were based on volunteerism. The data obtained from the interviews were analyzed by content analysis method. As a result of the analysis, the data revealed the perceptions of mathematics teachers about the concept of web-based distance education.

When the general opinions of mathematics teachers about webbased distance education were examined, it was seen that teachers expressed their opinions for each part of web-based distance education. Teachers mostly evaluated web-based distance education positively. Internet access and infrastructure problems were the issues that teachers focused on. Mathematics teachers have experienced web-based distance education through various platforms. In this experience, teachers had the greatest difficulty in the low number of students attending classes. Mathematics teachers evaluated the effect of web-based distance education on mathematics in terms of student, teacher, both student and teacher and mathematics teaching. Communication between studentteacher has been the subject that most of the teachers offered their ideas. While expressing the advantages and disadvantages of webbased distance education, teachers paid attention to the points that would make students' mathematics learning more effective. Student-teacher communication was one of them.

General thoughts of mathematics teachers on web-based distance education reflected quite different perspectives from each other. It is thought that the different perspectives of teachers may be working in different regions of Turkey, and be in different ages The majority of the teachers considered web-based distance education useful. Yorganc1 (2014) also suggested that web-based distance education can be an effective method in increasing students' success. Yazlık and Erdogan (2019) stated that web-based distance education facilitates students' understanding of mathematical concepts and increases their academic success.

Teachers discussed the impact of web-based distance education on each part of mathematics education. The most noticeable issue here is that most of the teachers think that web-based distance education is not effective and efficient on mathematics. Fedele and $\mathrm{Li}$ (2008) also emphasized that web-based distance education is insufficient for mathematics lessons on its own. In addition, Amin and Li (2010) stated that the relationship and support between students in mathematics lessons is an important factor for some students to overcome difficult obstacles.

Mupinga (2005) stated that one of the benefits of web-based distance education is that it provides flexibility of time and place for students. This flexibility is an advantage. Similarly, teachers stated that web-based distance education provides economy and time savings by providing many visual and audio materials for students. Ünsal (2012) stated advantages in web-based learning such as access to information, flexibility, repeatability, traceability, compliance with individual differences, relative to different learning styles, multiplicity of learning activities, progress at one's own pace, and low cost. In this study, as in Ünsal's (2012) study, teachers expressed the advantages of web-based education as repeatability, compliance with individual differences, multiplicity of learning activities, progress at their own pace and low cost.

Regarding the disadvantages of mathematics teachers in the mathematics learning-teaching process of web-based distance education, they emphasized the most common views of not being able to communicate with and control students. Koçer (2001) also stated that the most obvious disadvantage of distance education is that educators do not know the reactions of students, their participation in the lesson and whether they understand the subject. Students feel isolated in web-based education (Adams \& Timmins, 2006). Suggestions were made by teachers to teachers, parents, administrators and academicians who are experts in their fields in the web-based distance education system. The suggestions offered by the teachers are remarkable suggestions that will make the webbased distance education system better quality. Remedial work should be done in the light of these recommendations. It is recommended to create videos that will introduce teachers, students and parents to suitable digital platforms for education and explain how to use them, and share them through the relevant systems. In order to provide more effective mathematics teaching in web-based distance education, mathematics teachers need to develop themselves professionally and learn to use technological tools of web-based distance education at a high level. It is recommended to organize distance education seminars where this information will be shared by experts. In addition, courses on web-based distance education can be added to the programs in education faculties, or content related to effective web-based distance education can be added to the existing courses of the programs. For the administrators in the education system of our country, it is necessary to carry out reformative studies on equality of opportunity and infrastructure. Researchers need to do more studies on the web-based distance education system, which is the inevitable education system of the last period. In addition to teachers, it is thought that qualitative studies that gather the opinions of students based on their web-based distance education experiences will have a positive effect on solving recent education problems. Therefore, it is recommended to conduct studies that examine the views of students at all levels of education on web-based distance education. 
EK-1 Etik Kurul Onayı

IÜC Tarih ve Sayı: 23/09/2020-60633

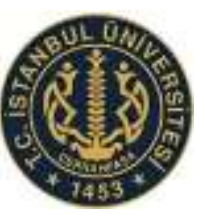

T.C.

ISTANBUL ÜNIVERSITESİ-CERRAHPAŞA

REKTÖRLÜĞÜ

Sosyal ve Beşeri Bilimler Araştırmaları Etik Kurulu

Başkanlığı

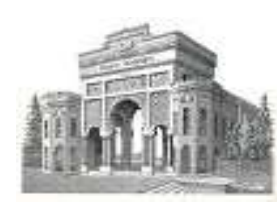

Say1 :74555795-050.01.04-

Konu : :2020-123 sayıl1 Etik Kurul Onay1

\section{Sayın Büșra KILLIT}

İÜC Lisansüstü Eğitim Enstitüsü

Matematik Eğitimi Bölümü

Yüksek Lisans Programı Öğrencisi

İlgi : :25.08.2020 tarihli proje başvurunuz.

Yürütücülüğünü üstlendiğiniz "Matematik Derslerinde Web Tabanlı Uzaktan Eğitime İlișkin Matematik Öğretmenlerinin Görüşleri" başlıklı "Araştırma Makalesi" başvurunuz etik açıdan uygun olduğuna oybirliği ile karar verilmiştir.

COVID-19 salgının Ülkemizde yayılması nedeniyle, Kurulumuz 02.09.2020 tarihinde on-line platformda gerçekleştirilen toplantısında yapılan değerlendirmeler sonucunda; elektronik belge sistemi (EBYS) ile uygunluğu bildirilen yazının ilgili makamlarca "Etik Kurul Onayı" yerine geçen belge olarak değerlendirilmesi hususunda;

Gereği için bilgilerinizi rica ederim.

$$
\text { e-İmzalı }
$$

Prof. Dr. Selçuk HÜNERLİ

Başkan

\section{ETIK KURUL ÜYELERI}

Prof. Dr. Selçuk HÜNERLİ (Başkan)

Prof. Dr. Fatma Yasemin KUTLU (Bşk.Yrd.)

Prof. Dr. Neșe KOCABAŞOĞLU

Prof. Dr. Hülya AŞKIN BALCI

Doç. Dr. Hanife Banu ATAMAN YANCI

Doç. Dr. Sevda KÜÇÜK 
EK-2: Yarı Yapılandırılmış Görüşme Formu

Adı:

Soyadı:

Yaş:

Öğretmenlikte deneyim yılınız nedir? :

Hangi sınıf düzeylerinde öğretmenlik yaptınız/yapıyorsunuz? :

Hangi ilde öğretmenlik yapıyorsunuz? :

\section{SORULAR}

1. Web (İnternet) tabanlı uzaktan eğitim hakkında ne düşünüyorsunuz?

2. Web tabanlı uzaktan eğitim ile ilgili deneyimleriniz nelerdir?

-Bu deneyimleri nasil yorumlarsiniz?

3. Web tabanlı uzaktan eğitimi kendi mesleki gelişiminiz açısından nasıl değerlendirirsiniz?

-Size katkiları neler oldu?

-Zorlandığınız kısımlar neler oldu?

4. Web tabanlı uzaktan eğitimin matematik öğrenme-öğretme sürecindeki etkileri nelerdir?

5. Sizce web tabanlı uzaktan eğitimin matematik öğrenme-öğretme sürecindeki avantajları nelerdir?

6. Sizce web tabanlı uzaktan eğitimin matematik öğrenme-öğretme sürecindeki dezavantajları nelerdir?

7. Web tabanlı uzaktan eğitimin matematik öğretim ve öğrenimi açısından kalitesini artırmak için önerileriniz nelerdir?

8. Web tabanlı uzaktan eğitim ile ilgili eklemek istediğiniz düşünceleriniz var mı? 